\title{
Lactic Acid Bacteria Resistance to Bacteriophage and Prevention Techniques to Lower Phage Contamination in Dairy Fermentation
}

\author{
A.K. Szczepankowska, R.K. Górecki, \\ P. Kołakowski and J.K. Bardowski \\ Additional information is available at the end of the chapter
}

http://dx.doi.org/10.5772/51541

\section{Introduction}

The first negative effect of bacteriophages on dairy fermentation was reported in the mid 30s of the XX century [1]. Regardless of sanitary precautions, starter strain rotations and constant development of new phage-resistant bacterial strains, phages remain one of the main and economically most serious sources of fermentation failures. Due to their natural presence in the milk environment, bacteriophages cause problems in industrial dairy fermentations world-wide. Their short latent period, relatively large burst size and/or resistance to pasteurization makes them difficult to eliminate [2]. Phage-induced bacterial cell lysis leads to failed or slow fermentation, decrease in acid production and reduction of milk product quality (e.g. nutritive value, taste, texture, etc.), which in effect cause profound economical losses [3]. An intriguing high number of bacteriophages of Lactococcus and Streptococcus bacteria reflects the biotechnological interest and engagement of the dairy industry in research on biology of these phages [4].

Since Lactococcus lactis strains are widely used as starter cultures for milk fermentation during manufacturing of many types of cheeses, sour cream and buttermilk, bacteriophages virulent against these strains appear commonly in the fermentation environment. It is estimated that $60-70 \%$ of technological problems in production of cottage and hard cheeses are caused by bacteriophage infection of bacteria from the Lactococcus genus [5]. The raise of interest in lactococcal phages due to economical aspects has subsequently led to a more global research on the biology of lactococcal phages, ways of their appearance in dairy environments and means of their elimination as well as characterization of phage resistance mechanisms encoded by bacteria exploited by the industry. 


\section{Lactic acid bacteria used in dairy industry}

Lactic acid bacteria (LAB) comprise different groups of microorganisms, such as Carnobacterium, Enterococcus, Tetragenococcus, Vagococcus, Weissella as well as species of genera which constitute the "industrial" core of LAB, like Lactococcus, Lactobacillus, Streptococcus, Pediococcus and Leuconostoc [6]. LAB reside in different natural habitats, including healthy and decaying plants, milk and dairy products, oral cavity and gastrointestinal tract of humans and animals. In addition, lactic acid bacteria can grow on meat and wine. These features are used in the production of fermented sausages (Lactobacillus, Pediococcus) and to improve the organoleptic characteristics of wine (Oenococcus oeni) [6].

The genus Lactococcus is the best characterized food-related LAB. As lactococcal strains are able to grow in milk and transform lactose to lactic acid, they are commonly used as starter cultures in industrial fermentations for cheese production. The ability of LAB to transform raw milk into other products suitable for consumption has been used by man for millenniums. Such long history record of interactions of man with lactic acid bacteria and present knowledge led to assigning these bacteria the GRAS status (generally recognized as safe) [7]. Dairy products and the respective LAB species are gathered in Table 1 based on specifications and recommendations released by the main culture suppliers.

A typical lactococcal mixed starter culture consists of 2-3 well defined strains, which specific properties have significant impact on the texture and flavor of the end product. Nowadays, large dairy plants process up to $10^{6}$ liters of milk per day, producing annually approximately $10^{7}$ tons of cheese [8]. Therefore, technological problems in production of cottage and hard cheeses caused by bacteriophage infections have serious economical consequences.

\section{Lactic acid bacteria phages - history background, morphology, classification}

The history of discovery of bacteriophages originates in the research of Felix d'Herelle and Frederick Twort in the beginning of the XX century and further development of phage biology studies spans the fourth quarter of the last century. Bacteriophages (phages) are defined as viruses that exert their activity against prokaryotic cells - both bacterial as well as archeal.

The name "bacteriophage" derives from the Greek word "phagein", meaning "to eat", which points to their destructive action. Bacteriophages exist in two states - extra- and intracellular - which place them half-way between live organisms and non-viable forms. As obligate intracellular parasites their survival is dependent on host organisms. Phage "life functions", such as genome replication and synthesis of capsid components, are restricted to occur within infected cells. Outside of the host phages are regarded as metabolically inert, unable to carry out neither biosynthetic nor respiratory functions.

Phages intrigue by their simplistic organization and submicroscopic sizes. These infectious particles consist of a single- or double-stranded nucleic acid genome (DNA or RNA), 
enveloped in a protein structure (capsid). Current taxonomy and classification of bacteriophages rely on the type of nucleic acid genome and phage morphology, physiology (temperate and virulent life cycles) and genomics. Taxonomy of viruses is supervised by the International Committee for Taxonomy of Viruses (ICTV) that imposes rules for names and writings.

\begin{tabular}{|c|c|}
\hline Product & LAB species \\
\hline Yoghurt & $\begin{array}{l}\text { Streptococcus thermophilus, Lactobacillus delbrueckii subsp. } \\
\text { bulgaricus }\end{array}$ \\
\hline $\begin{array}{l}\text { Cottage cheese, Cheddar, } \\
\text { Pasta Filata }\end{array}$ & $\begin{array}{l}\text { Lactococcus lactis subsp. lactis, Lactococcus lactis subsp. } \\
\text { cremoris } \\
\text { Streptococcus thermophilus* }\end{array}$ \\
\hline Tvarog, blue cheese & $\begin{array}{l}\text { Lactococcus lactis subsp. lactis, Lactococcus lactis subsp. } \\
\text { cremoris } \\
\text { Lactococcus lactis subsp. lactis var. diacetylactis, } \\
\text { Leuconostoc mesenteroides subsp. cremoris } \\
\text { Leuconostoc mesenteroides subsp. mesenteroides }\end{array}$ \\
\hline $\begin{array}{l}\text { Butter milk, fermented cream, } \\
\text { butter }\end{array}$ & $\begin{array}{l}\text { Lactococcus lactis subsp. lactis, Lactococcus lactis subsp. } \\
\text { cremoris } \\
\text { Lactococcus lactis subsp. lactis var. diacetylactis }\end{array}$ \\
\hline Ryazanka & Streptococcus thermophilus ${ }^{* *}$ \\
\hline Cheddar, Feta & $\begin{array}{l}\text { Lactococcus lactis subsp. lactis, Lactococcus lactis subsp. } \\
\text { cremoris }\end{array}$ \\
\hline Mozzarella, Pizza cheese & $\begin{array}{l}\text { Streptococcus thermophilus, Lactobacillus delbrueckii subsp. } \\
\text { bulgaricus }\end{array}$ \\
\hline $\begin{array}{l}\text { Masdamer, Gouda, Edam, } \\
\text { Tilsitter, soft mould ripened } \\
\text { cheese, quark, fermented milk } \\
\text { beverages }\end{array}$ & $\begin{array}{l}\text { Lactococcus lactis subsp. lactis, Lactococcus lactis subsp. } \\
\text { cremoris } \\
\text { Lactococcus lactis subsp. lactis var. diacetylactis } \\
\text { Leuconostoc mesenteroides subsp. cremoris }\end{array}$ \\
\hline $\begin{array}{l}\text { Mozzarella, Swiss, stabilized } \\
\text { soft mould ripened cheese }\end{array}$ & Streptococcus thermophilus \\
\hline Swiss, Grana & Lactobacillus helveticus, Lactobacillus delbrueckii subsp. lactis \\
\hline $\begin{array}{l}\text { Fermented cream, fermented } \\
\text { milk beverages }\end{array}$ & Lactobacillus acidophilus, Streptococcus thermophilus \\
\hline Actimel@-like products & $\begin{array}{l}\text { Lactobacillus casei, Lactobacillus paracasei subsp. paracasei } \\
\text { Lactobacillus rhamnosus, Lactobacillus acidophilus }\end{array}$ \\
\hline Swiss, Italian & $\begin{array}{l}\text { Lactococcus lactis subsp. lactis, Lactococcus lactis subsp. } \\
\text { cremoris } \\
\text { Lactococcus lactis subsp. lactis var. diacetylactis } \\
\text { Lactobacillus helveticus, Lactobacillus delbrueckii subsp. lactis }\end{array}$ \\
\hline
\end{tabular}

* seldom applied in cottage cheese, ${ }^{* *}$ texturizing strains

Table 1. Various dairy products and LAB species applied in their production. 
The majority of known viruses are bacteriophages, which infect cells of Eubacteria and Archaea. It is also accepted that most phages (96\%) isolated so far belong to one taxonomic order of Caudovirales [9]. Bacteriophages within this order contain tails and a linear dsDNA genome. They are further classified into three phylogenetically linked families of: Myoviridae, Siphoviridae, Podoviridae [9]. Myoviridae phages contain a long and contractile tail, while Siphoviridae and Podoviridae are equipped with a non-contractile tail, long and short, respectively [10]. Isometric heads are dominating (85\%) in the morphology of phages from all three families [11]. It is worth to mention that $61 \%$ of known phages are classified into the Siphoviridae family, of which most of them infect strains of enterobacteria (906 phages), Lactococcus (700), Bacillus (380) and Streptococcus (290) [9]. Apart from the tailed Caudovirales phages, there are others demonstrating filamentous, pleomorphic or polyhedral morphology.

Bacteriophages, although simple in organization, are the most diverse life forms in the biosphere. Their apparent heterogeneity is reflected by various features - both morphological as genetic, and their persistence on Earth, estimated as high as $10^{31}$, outnumbers by far their bacterial hosts [12]. Phages inhabit various niches, like oceans [13], thermal waters [14], gastrointestinal tract [15] and superficial ecosystems created by man, including fermentation tanks in dairy industry [16]. Hence, their impact on the microbial world cannot be underestimated.

Bacteriophage genome structure, indicating linear and double-stranded characteristics of the DNA molecule, containing or not cohesive ends and sometimes presenting terminal redundancy and circular permutation, describes the general feature of LAB phage genomes.

\section{Molecular mechanisms of phage infection of LAB}

To enter the host, phages firstly come in contact and adsorb to the bacterial cell wall. The adsorption process has been well studied in Gram-negative bacteria, where it was found that two components are involved in the phage-host interaction. One of them is a receptor located in the bacterial cell envelope (membrane or wall), whereas the second component, called the receptor binding protein (RBP), is presented on the phage surface. RBP is responsible for recognition and binding of the phage particle to the bacterial receptor [17]. In the first stage of phage infection, the RBP protein recognizes and binds to a suitable sugar receptor. However, such binding is reversible and thus, the initial phage-bacteria interaction does not ensure commencement of a successful infection event. In contrast to this, in the second stage, a stable phage attachment to the bacterial cell occurs due to an irreversible binding between proteins located on bacterial and phage surfaces [18]. Both stages of adsorption are observed in Gram-positive bacteria: phages that attack Lactococcus lactis cells bind to specific receptors, mainly sugars, located in the cell wall. It is widely known that rhamnose, glucose, galactose, and galactosamine are compounds with which the phage RBP interacts at the initial stage of adsorption [19]. In the case of Lactococcus c2-type phages, effective infection requires interaction between phage and the bacterial protein Pip (phage infection protein) [20]. The Pip protein of L. lactis is an integral membrane protein [21] and 
its interaction is crucial both for establishing the reversible and irreversible contact between the phage and the host. In contrast to c2-type phages, phages representing P335 and 936 groups bind to other various bacterial membrane proteins and have been examined in a lesser extent [22]. After establishing a tight connection, they inject their genetic material inside the host cytoplasm, while the capsid remains outside the cell. Then, subsequent steps of phage infection are effectuated which follows either the lytic or lysogenic life cycle. Phages entering the lytic mode immediately redirect the host replication machinery and metabolic functions to replicate its own genetic material and synthesize phage encoded proteins. In effect, abundant amounts of progeny particles are produced. Phages executing only the lytic cycle are designated as virulent and their infection implicates cell death. Yet, certain phages termed as temperate can lead an alternating existence between a dormant state inside the bacterial cell and lytic growth. These phages can exist in the cell in a latent form for generations, replicating in synchrony with the bacterial chromosome. A dormant form of the phage is called a prophage and leads a lysogenic life cycle in a bacterial host strain, which is regarded as a lysogen. Conversion from the lysogenic life cycle to the lytic often occurs spontaneously or can be induced by various mutagens (UV, mitomycin).

\section{Phage sensitivity of LAB starters used in dairy industry}

Virulent phages of Lactococcus lactis spp. are the most frequently encountered phages in milk plants during cheese and dairy beverages production. Additionally, phages attacking Streptococcus thermophilus are often observed in cheese and less distinct in yoghurt manufacturing. Phages against Lactobacillus spp. and Leuconostoc spp. starter cultures represent a minor problem [23]. Currently, in production of dairy beverages functional Lactococcus and Streptococcus thermophilus texturizing strains with ability to produce exopolysaccharides (EPS) are commonly used. In nature it is very difficult to find strains with similar rheological properties differing in resistance to phages. Thus, phage contamination of texturizing strains can lead to serious problems in ensuring quality dairy products.

\section{Defense mechanisms of lactic acid bacteria}

It is well documented that lactic acid bacteria evolved defense systems against bacteriophages, which allow them to survive in an environment full of their predators. These anti-phage systems have been organized into five groups depending on the manner by which they operate: (i) inhibition of phage adsorption, (ii) blocking of phage DNA injection, (iii) restriction modification systems, (iv) phage abortive infection systems, and finally, the most recently described, (v) CRISPR/cas systems. The knowledge about natural phage resistance mechanisms together with a set of genetic tools were applied to develop also (vi) engineered defense systems that confer higher levels of resistance and/or broader phage specificity.

\subsection{Inhibition of phage adsorption}

Basic mechanisms of inhibition of phage adsorption to the bacterial cell are associated either with physical masking of the receptor or with changes in its structure, or even with its 
absence in the cell envelopes [24]. Lack of a functional receptor might be due to spontaneous mutations in the genetic material, leading in turn to bacteriophage insensitive mutants (BIM). A good illustration of the BIM phenomenon is a lactococcal mutant in the chromosomally-encoded pip gene. The resultant strain is unable to interact with phages of the c2 group, revealing high level of c2-specific resistance [24] (for further details on BIMs see section 12.2.).

Mechanisms preventing phage adsorption are not only mediated by the bacterial chromosome, but also by acquired plasmids. The best documented plasmid-encoded mechanisms of inhibition of phage adsorption rely on either direct synthesis of cell surface antigens or the production of extracellular carbohydrates. Of the two modes of action, the former reveals phage specificity, whereas the latter seems to restrict access to the bacterial cell for various harmful factors, including bacteriophages [25]. Studies carried by Tuncer and Akcelic demonstrated that a 28.5-kb plasmid, isolated from L. lactis subsp. lactis MPL56, causes complete inhibition of four lactococcal phages due to the production of a 55.4-kDa protein [25]. The protein exhibits similarity to lectins, a group of proteins that adsorb to specific monosaccharide components of polysaccharides in the cell wall, hence, impairing specific recognition of the phage receptor sites by these four phages. Thus, this plasmidencoded 55.4-kDa protein shields specifically the galactose-containing receptor rather than interacts with the phage, in other words, the bacterial lectin and the phage RBP compete for the receptor [25]. Another example of physical masking of the receptor is the plasmidmediated production of extracellular carbohydrates, called exopolysaccharides (EPS) [26]. Such EPS envelope coats the cell surface giving bacteria extra protection, not only against bacteriophages, but also against desiccation. There is some evidence that EPSs contain sugar residues that are similar or even identical to initial phage receptors. Therefore, phage insensitivity of LAB strains that carry EPS-encoding plasmids, for instance, $\mathrm{pCI} 658$, might be due to phage immobilization by binding to EPS [26]. On the other hand, polysaccharides have an impact on the properties of dairy products, like: texture, viscosity and smoothness of mouthfeel. Thereby, application of EPS-producing phage-resistant strains might be limited to a narrow range of dairy products [25-26].

\subsection{Blocking of phage DNA injection}

After phage binding to the receptor, phage DNA is introduced into the bacterial cell. In the cytoplasm, phage genetic information is amplified and consequently progeny particles are produced. However, studies of Watanabe on the interaction between phage PL-1 and a Lactobacillus casei strain showed no bacterial lysis, despite phage adsorption to cell envelopes [27]. An electron microscopy image indicated that the phage DNA remains intact in the capsid. In contrast to this, a significant increase in the number of empty capsids was observed on the surface of the sensitive strain. In the light of this evidence, it is obvious that phage DNA injection might be interrupted, although the adsorption of phages to the cell surface occurred. Intensive attempts to elucidate the injection blocking phenomenon have allowed identifying different Sie (superinfection exclusion) or Sie-like systems. On the other 
hand, only few of them have been well characterized [28]. Therefore, the mechanism preventing entry of phage DNA to the cell is still poorly understood, both in LAB and other microorganisms. Surprisingly, it was discovered that most sie genes are located within the prophage regions of the bacterial chromosome [28]. However, the first lactococcal injection blocking system was identified on the pNP40 plasmid, which blocks DNA penetration specifically for $\phi c 2$ phage of the lactococcal c2 phage group [29]. As it was described in the previous section, the membrane Pip protein is essential for $\mathrm{c} 2$ adsorption to Lactococcus lactis. It was speculated that the pNP40-encoded protein product might have an impact on the activity, production, or membrane insertion of Pip, thereby affect its biological function and prevent phage DNA entry [29]. The first description of a sie system of Lactococcus was published in 2002 and referred to the P335-type temperate lactococcal bacteriophage Tuc2009 [30]. After integration of the bacteriophage Tuc2009 genome into the lactococcal chromosome, the prophage protein Siezoog is produced and blocks superinfecting phage DNA entry into the cell. The blocking mechanism has not been fully elucidated; nevertheless, it has been proposed that Siezoog interacts with factor(s) responsible for initiating the phage DNA release from the capsid. Alternatively, the Siezong protein might interact with cell membrane proteins that are essential for DNA translocation. The effect of Siezoog seems to be analogous to the effect of the lysogenic phage repressor $(\mathrm{CI})$ preventing re-infection. In contrast, the presence of the siezoog gene determines resistance to various phages, also to phages from other species [28,30]. Similarly to lactococci, in lactobacilli prophages are also a common phenomenon [31]. Comparative genomics of lactobacilli revealed the presence of genes coding for putative proteins with a close sequence match to a surface-exposed lipoprotein encoded by bacteriophage TP-J34 of Streptococcus thermophilus, another bacterial species used in industrial milk fermentation processes. The TP-J34 prophage carries a Sie-like system consisting of the ltp (lipoprotein of temperate phage) gene, encoding a surface-exposed lipoprotein of biologically proven phage-resistance functions. In view of the fact that the sie genes of lactic acid bacteria are located on lysogeny modules of prophages and confer infection exclusion, they have been termed phage-derived phage resistance systems [32].

\subsection{Restriction modification systems}

Following successful injection of DNA, phage infection might be completed or hindered by the presence of restriction modification systems (RM). RM systems comprise two activities represented by the following enzymes: endonuclease (restriction) and methyltransferase (modification) [33]. Simultaneously, both activities are specific to the same target sequences. The endonucleolytic activity is responsible for degradation of invading foreign DNA, including phage DNA, which lack a unique methylation pattern, while the methyltransferase activity protects the host DNA against degradation by introducing a methyl group into a specific nucleotide of the target site [34]. In detail, phage DNA usually reveal different methylation patterns than those recognized by innate RM systems. Unmethylated target sequences are significantly susceptible to endonucleolytic attack, 
resulting in DNA degradation [35]. Such mode of action guarantees that the presence of RM systems limits phage proliferation in the cytoplasm, causing no harm to the cell. RM systems are classified into four groups, based on their molecular structure, co-factor requirements, sequence recognition and cleavage position [34-36].

\subsubsection{Type I RM}

Type I is the most complex RM system in terms of genetic organization and biochemical activity. It is composed of three different $h s d$ (host specificity determinant) genes coding for the following subunits: HsdR - responsible for restriction, HsdM - involved in modification and HsdS - responsible for specific sequence recognition. None of them reveals any activity as a single protein [36]. In order for the modification activity to occur, a combination of one HsdS and two HsdM subunits is required. The $\mathrm{M}_{2} \mathrm{~S}_{1}$ multifunctional enzyme acts as protective methyltransferase, which modifies DNA through the transfer of the methyl group from S-Adenosyl-methionine (AdoMet) to the specific adenines in the recognition site $[36,38]$. For restriction activity, all subunits are absolutely required in a stoichiometric ratio of $\mathrm{R}_{2} \mathrm{M}_{2} \mathrm{~S}_{1}$. This holoenzyme exhibits both endonucleolytic and helicase activities, and is active only in presence of $\mathrm{Mg}^{2+}$, AdoMet and ATP [36].

Besides the complex structure of this multifunctional enzyme, also structure of the recognized sequences and cleavage position are the distinguishing features of type I RM systems. Type I RM enzymes specifically recognize asymmetric and bipartite sequences. These non-palindromic DNA sequences consist of two specific components, one of 3-4 bp and the other of $4-5 \mathrm{bp}$, separated by a $6-8 \mathrm{bp}$ non-specific sequence [34,36-37]. The innate methylation state of the target sequence determines the activity of the multifunctional $\mathrm{R}_{2} \mathrm{M}_{2} \mathrm{~S}_{1}$ enzyme. When the target sequence is methylated or semi-methylated (e.g. just after replication), the enzyme will exhibit activity of a methyltransferase, which completes DNA modification. In contrast, if the holoenzyme binds to an unmethylated recognition site, DNA translocation past the DNA-enzyme complex occurs in an ATP-dependent manner [35,38]. In spite of DNA translocation, the enzyme remains bound to the target site. DNA is cleaved at a position, where either collision with another translocating complex has appeared or translocation is halted due to the topology of the DNA substrate. Consequently, type I restriction enzymes cleave DNA randomly at a nonspecific site, far from the recognition sequence [38].

Interaction between subunits, leading to formation of multifunctional enzymes as well as interaction of resultant enzyme molecules with DNA, are determined by the structure of the HsdS subunits. HsdS subunits consist of regions, which amino acid sequences are conserved within an enzyme family, and two independent target recognition domains (TRD) that share low level of amino acid identity [34,39]. TRDs are involved in target sequence recognition, each TRD recognizes one-half of the split target site and is responsible for DNA binding. Since TRDs are highly variable, they recognize multiple target sequences, and thus, provide a variety of phage resistance types [34,36,39]. The central domain, located between two TRDs, is responsible for interaction with one HsdM subunit. Other conserved regions 
located at $\mathrm{N}$ and $\mathrm{C}$ termini have been proposed to form a split domain, which makes contact with a second HsdM subunit [35,37].

Type I systems have been further classified into four families based on genetic and biochemical criteria, such as: gene order, identity at amino acid level, complementation assay and enzymatic properties. RM systems belonging to type IA, IB, and ID are only chromosomally-encoded, while most complete type IC systems are either chromosomal or carried on large conjugative plasmids [36]. Additionally, numerous small plasmids carry the $h s d S$ gene alone $[34,40]$. While all subunits belong to the same subtype, a plasmid-encoded HsdS protein is able to form a multifunctional enzyme with chromosomally-encoded HsdM and HsdR subunits [41]. Thus, acquisition of a new $h s d S$, revealing new sequence specificity, leads to the increase of phage resistance.

Among LAB, type IC systems seem to be most widespread. Type IC RM loci of both L. lactis IL1403 and L. cremoris MG1363 consist of three genes: $h s d R$, $h s d M$, $h s d S$, and two promoters, one for transcription of $h s d R$ and the other for transcription of both $h s d M$ and $h s d S[17,42]$. Nevertheless, there is no clear evidence for transcription regulation of type I RM enzymes [42]. Under these circumstances, an unmodified chromosome is exposed to endonucleolytic digestion after acquisition of either a new system or just the subunit specificity genes. It was observed that a delay in the appearance of restriction activity, which ensures the survival of recipient cells in the absence of complete modification of chromosomal target sites, depends on host function [36,43]. Chromosomally-encoded energy-dependent proteases ClpP and ClpX, co-operating in a complex, are implicated in the regulation of restriction activity [36]. The ClpXP complex is responsible for restriction alleviation through proteolytic degradation of HsdR subunits. Based on results of Janscak and colleagues concerning the EcoR124I endonuclease, an alternative mechanism of delay in restriction alleviation has been proposed. As each of the two HsdR subunits interacts differently with HsdM, it has been postulated that the control of restriction activity is implemented at the level of subunit assembly [38]. Formation of a weak $\mathrm{R}_{2} \mathrm{M}_{2} \mathrm{~S}_{1}$ restriction complex will be suspended, unless accumulation of HsdR molecules occurs. Excess of HsdR over HsdM is observed in the late stage of establishing of the RM system in a recipient cell; hence, the unmodified chromosome is protected against premature restriction activity [38].

\subsubsection{Type II RM}

In contrast to type I, type II RM systems are structurally the simplest of all restriction modification systems. They are generally encoded by two genes, but the key defining feature of this RM type is the independent activity of restriction and modification enzymes [33]. Methyltransferase is active as an asymmetric monomer, requires only AdoMet, and recognizes the same target sequences as the cognate endonuclease. In contrast, restriction endonuclease is a homodimer and requires divalent $\mathrm{Mg}^{2+}$ cations for proper activity. Endonucleases generally recognize a palindromic 4-8 bp DNA sequence and cleave within or in a fixed distance of the recognition site. In contrast to type I, ATP has no effect on the cleavage activity of type II endonucleases [44]. 
As this RM type is more heterogeneous in respect to endonucleolytic activity than originally thought based on their structural simplicity, the described mode of action refers mainly to typical (orthodox) type II endonucleases [45].

Apart from the orthodox type (called IIP), type II restriction enzymes have been categorized into the following subclasses: IIA, IIB, IIC, IIE, IIF, IIG, IIH, IIM, IIS and IIT. Endonucleases of these subclasses differ in structure of the recognized sequence (asymmetric or symmetric), cleavage positions and cofactor requirements. Type IIA endonucleases behave similarly to the orthodox class, but recognize asymmetric sequences [45]. The unique feature of subclass IIB refers to the cleavage position. These endonucleases cut DNA from both sides, which results in complete extraction of the target sequence from the DNA molecule [46]. Subclasses IIC and IIE have both modification and restriction domains present in one polypeptide. Additionally, class IIE endonucleases interact with two copies of their recognition site, one copy being the target for cleavage, the other serving as an allosteric effector [47]. Similarly to subclass IIE, class IIF restriction enzymes interact with two copies of their recognition sequences, but cleavage occurs at both sequences. Type IIG restriction enzymes seem to combine properties of both IIB and IIC subclasses. The methyltransferase activity of class IIG, like IIB, is stimulated by AdoMet. The main similarity between IIG and IIC is that they both have restriction and modification activities located on one polypeptide chain [45,47]. Subclass IIH, represented by the AhdI system, appears to be a novel RM system due to its genetic organization resembling that of type I. As in type II systems, the AhdI endonuclease is encoded by a single gene; on the other hand, similarly to type I, its cognate methyltransferase forms a complex consisting of two modification and two specificity subunits [44,48]. Subclass IIM is at the opposite extreme from other type II subclasses as it recognizes and cleavages methylated target sequences. The key distinguishing feature of type IIS is the cleavage position outside of the recognition sequence at a defined distance [49]. Subclass IIT is an example of a variation in the typical genetic organization of type II RM systems, as the endonuclease is composed of two different subunits. Moreover, some IIT endonucleases function not only as heterodimers, but also as heterotetramers [44-45].

As enzymes belonging to type II systems are the most abundant and mainly encoded on plasmids, they can be acquired by the bacterial cell through plasmid transfer events. Therefore, a question arises as how to protect the host cell against an incoming endonuclease. In many cases, each gene of the type II RM system has its own promoter. Thus, a delay in appearance of the endonuclease activity is regulated at the transcriptional level. The lactococcal LlaDII RM system is a good example which illustrates this type of regulation [50]. At the initial stage of establishing in the host cell, the LlaDII methyltransferase is overexpressed, whereas the restriction enzyme is produced in small amounts due to the weak constitutive expression of its gene. On the other hand, a permanently high concentration of methylases is an unfavorable circumstance due to possible methylation and therefore protection of the invading phage DNA. The LlaDII methyltransferase contains HTH motifs, which were shown to be engaged in direct interaction with its promoter sequence, causing silencing of its own gene expression [50]. 


\subsubsection{Type III RM}

Unlike types I and II, type III systems are less spread among lactic acid bacteria. The LlaFI system identified on the lactococcal pND801 plasmid is the first type III RM system described not just in LAB, but generally in Gram-positive bacteria [51]. Based on computational analyses of genome sequences, type III systems were observed to occur also in lactobacilli (for instance Lactobacillus johnsonii and Lb. rhamnosus) [52]. On the one hand, type III resemble type II systems in their structural and genetic organization. Type III, like type II systems, consists of two genes, one encoding a methyltransferase (Mod) and the other - an endonuclease (Res). Mod is responsible for binding and methylating the recognition sequences, regardless of the presence of Res. On the other hand, type III systems are similar to type I, in respect to endonuclease activity, as the Res subunit is only active in a complex with Mod. Another basic similarity to type I systems is the fact that they both comprise the helicase domain and require both AdoMet and ATP for full restriction activity. The distinctive features characterizing type III systems concern recognition sequences and cleavage sites. The Mod subunit recognizes asymmetric, opposite-oriented sequences and methylation takes place only on one strand of the DNA [53]. The Res endonuclease cuts both strands of the DNA at the distance of 24-27 nucleotides downstream of the unmethylated specific sites [53].

Lactococci have been found to possess three types of RM systems: type I, II and III. Based on genomic sequence data, it is evident that RM genes are both chromosomally- and plasmidencoded. However, a variety of RM determinants is generally associated with plasmids [17]. In contrast, very few phage defense mechanisms have been described for $S$. thermophilus. In 2001, Solow and Somkuti reported on the discovery of a complete type I RM system encoded on a streptococcal plasmid pER35 [54]. Further progress in genome sequencing led to finding complete type I and III RM systems in chromosomes of S. thermophilus strains. Genome sequence analyses revealed that lactobacilli, like lactococci and streptococci, possess in their chromosomes three types (I-III) of RM systems [55].

\subsubsection{Type IV RM}

To date, no type IV RM systems has been distinguished in lactic acid bacteria. It is highly likely that in the future members of this class will be discovered in LAB. For that reason as well as from the evolutionary point of view, the type IV RM system is worth mentioning. A fusion of genes coding for Mod and Res subunits of type III systems was a key step for evolution of type IV RM [56]. The resulting endonuclease (revealing also methyltransferase activity) has an asymmetrical recognition sequence and cleavage occurs at a fixed distance from the recognition site, like for the type IIS enzymes. On the other hand, this endonuclease requires AdoMet, which distinguishes it from type II endonuclease activity. Therefore, taking into account the enzymatic features of model type IV Eco57I and BseMII endonucleases, it has been hypothesized that type IV endonucleases are an intermediate between type III and type IIS enzymes. 
In summary, it has been well documented that phage restriction-modification systems are widely spread among lactic acid bacteria. Nevertheless, comparative genomics of LAB demonstrated that bacteria representing different niches vary in the presence of restrictionmodification genes. The lack of RM systems is a common feature for LAB isolated from the gut, whereas the presence of RM genes is a typical feature for dairy species. Therefore, it was proposed that genes constituting the restriction-modification systems, together with certain genes of sugar metabolism and the proteolytic system, constitute "a barcode" of genes, which can indicate the ability of the microorganism to occupy either dairy or gut niches [57].

\subsection{Phage abortive infection systems}

When the RM systems fail in protecting the bacterium against invading phage DNA, initiation of the phage propagation cycle occurs. However, proliferation of progeny particles might be dramatically limited due to systems that abort the infection at various points of the phage cycle. Abortive infection mechanisms (Abi) have different targets in the cell. They are able to interrupt phage DNA replication, transcription, protein synthesis, phage particle assembly or induce premature cell lysis $[17,58]$. The Abi mechanisms have been found in many bacterial species, including Escherichia coli, Bacillus subtilis, Streptococcus pyogenes, Vibrio cholerae and Lactococcus lactis [58]. The most known Abis have been found in the latter species. To date, 22 lactococcal Abi mechanisms have been identified and designated into various groups distinguished by a subsequent letter of the alphabet [58-60]. Most of Abi systems are plasmid-encoded and only three are located on chromosomal DNA $(a b i \mathrm{H}, a b i \mathrm{~N}$, $a b i \mathrm{~V})$ [60]. For instance, $a b i \mathrm{~N}$ is located in a prophage region of the L. lactis subsp. cremoris MG1364 genome and exhibits significant similarity to a corresponding region of the lactococcal temperate phage rlt [61]. Abi systems present simple genetic organization. The Abi phenotype is most frequently encoded by a single gene; however, more complex structures have been identified in six systems. AbiE, AbiG, AbiL, AbiT and AbiU are encoded by two genes, whereas AbiR is the only system identified until now that is encoded by three separate genes [58, 62-63]. Proteins encoded by abi genes are cytoplasm-located, where they reveal their activity. In contrast, the AbiP system is represented by a membraneanchored protein [64].

Abi systems reveal a variety of modes of action. However, in many cases, mechanisms of action of the individual systems were not fully elucidated. Some Abis, like AbiA, AbiD1, $\mathrm{AbiF}, \mathrm{AbiK}, \mathrm{AbiP}$ and AbiT, have been found to interfere with DNA replication, whereas $\mathrm{AbiB}, \mathrm{AbiG}$ and $\mathrm{AbiU}$ arrest mRNA synthesis or have a negative impact on stabilization of transcripts. Haaber and colleagues presented that the AbiV system strongly affects translation of both early and late phage proteins, shortly after infection. Based on this observation, it was concluded that the $\mathrm{AbiV}$ system arrests the bacterial translation apparatus [60]. AbiE, AbiI, AbiQ and AbiZ systems affect maturation of phage particles [59,65]. The AbiZ system, identified in 2007 by Durmaz and Klaenhammer, induces premature lysis of phage-infected cells, resulting in the release of the developing phage 
particles before completion of the maturation process. The timing of phage lysis is controlled by the phage holin protein; thus, AbiZ might interact cooperatively with the phage holin or with a holin inhibitor to make it active prematurely [59].

While the mechanism of cell death in the AbiZ system is self-explanatory, in case of other Abi systems is poorly elucidated. The most likely explanation for this phenomenon is that Abi proteins interfere with processes essential not only for phage, but also for bacterial development; therefore, death of individual bacterial cells is always observed following activation of the Abi systems [17,58-59]. As a consequence, release of progeny particles is limited and the bacterial population survives. Hence, the Abi systems constitute a barrier against bacteriophage proliferation, in which "altruistic suicide" of infected bacterial cells provides protection of the whole uninfected population $[17,58]$.

\subsection{CRISPR/cas systems}

Another naturally-occurring distinct phage defense system recently described in Prokaryotes is CRISPR/cas. Besides RM mechanisms, this system is also directly engaged in protecting bacterial cells against invading genetic elements, such as phages or plasmids [66]. In brief, CRISPR-conferred phage resistance relies on incorporation of short phage-derived sequences within specific loci of the bacterial genome. In effect, the bacterial cell becomes immune to phages which carry homologous sequences.

CRISPR/cas systems are composed of two specific determinants: (i) clustered regularly interspaced short palindromic regions (CRISPR array) and (ii) regions encoding CRISPRassociated (Cas) proteins. The CRISPR arrays consist of non-coding sequences composed of unique phage-derived spacers (21-72 bp) separated by short direct repeated sequences (21$48 \mathrm{bp}$ ) of bacterial origin. The length of spacers and repeats within a single array is always the same, while their number may vary from $2-375$, depending on the species. On the other hand, Cas proteins constitute a heterologous group of proteins, which contain various functional domains, e.g. typical for nucleases, helicases, nucleic acid binding proteins, etc. [66]. The specific role of individual Cas proteins vary as they were shown to be engaged at various stages of CRISPR-conferred resistance. Interestingly, cas genes were detected only in CRISPR-containing genomes, suggesting their tight association. The number of cas genes within a CRISPR locus varies from 4 to 20 [67]. Their position can be either upstream or downstream of repeat-spacer units, but always from the same side for a given CRISPR locus type. The CRISPR array and Cas-encoding genes are separated by an A-T rich leader region, suggested to be the promoter region of CRISPR transcription; yet, mechanisms regulating expression still remain to be elucidated [68]. Together these two elements, CRISPR spacerrepeat array and Cas proteins, provide "immunity" to the bacterial cell against invading foreign DNA molecules, including phages (for detailed review see: [67-69]). CRISPR arrays are widely distributed within the Prokaryotic world and are detected in the genomes of $40 \%$ of Bacteria and $90 \%$ of Archea [70]. Depending on the species, a single genome can carry up to 18 CRISPR loci, which are suggested to confer resistance to various phages [66]. 
The mechanism of CRISPR/cas conferred protection of bacterial cells against phage infection is rather complex and can be divided into three main stages: (i) adaptation, (ii) CRISPR expression and (iii) CRISPR-mediated interference. The first stage relies on incorporation into the bacterial genome within the CRISPR locus of short phage-derived fragments (protospacers). Despite the fact that the exact mechanism of spacer acquisition is not known, it is not accidental. Recognition of specific phage sequences for integration is suggested to be linked with sequences termed PAMs (proto-spacer adjacent motifs), located up- or downstream of the proto-spacer. Integration of new spacers occurs from the end of the leader region, between the palindromic repeats and involves certain Cas proteins. Stage 2 is CRISPR expression, which involves transcription of the whole CRISPR spacer-repeat array (pre-mRNA). The presence of palindromic repeat sequences within the transcript, leads to formation of secondary hair-pin like structures. These are subsequently processed into short CRISPR RNAs (crRNAs) by endonucleolytic digestion at a cleavage site located downstream from the last nucleotide forming the hairpin. Finally, the last stage of CRISPR/cas activity is based on interaction of mature crRNAs with invading foreign DNA elements (phages), which leads to silencing/degradation of the latter by a certain group of Cas proteins. By this activity, CRISPR/cas-carrying hosts are protected from invasion by phages carrying sequences homologous to the integrated spacers. Application of the CRISPR/cas system for developing novel phage resistant dairy starter strains may be an attractive alternative, which will be discussed in further parts of this chapter (see section: 12.4.).

\subsection{Engineered defense systems}

Besides the naturally-occurring defense mechanisms against recurrent phage infections (discussed above), new methods involving molecular techniques are designed to combat phages. The constantly growing knowledge on phage development and their genome sequences allows currently to develop engineered defense systems, which are otherwise not encountered in nature (for review see also: [71]). The idea of such systems relies on engineering bacterial strains in a way which impairs genes vital for phage development, e.g. phage replication proteins or other replication factors. Moreover, identification of homologues of these crucial genes within multiple phage genomes allows creating broadrange phage defense systems. As presented below, numerous studies deliver clear evidence that such engineered systems provide efficient protection against phage infections. The following parts of this chapter will delineate each of these systems in more details. Studies on developing engineered systems for lactic acid bacteria were performed in most part in Streptococcus thermophilus and Lactococcus lactis as strains from both species find wide applications in dairy fermentation processes.

\subsubsection{Antisense RNA-based phage defense systems}

Bacterial-engineered expression of antisense RNA directed against phage transcripts has been described as one of the most efficient phage defense systems. The mode of action of such RNAs is hybridization to phage sense strand RNAs upon infection. By these means the 
system interferes with the phage life cycle, inhibiting translation of essential phage genes or degradation of their mRNAs [72].

An example are systems developed in Streptococcus thermophilus, which were shown to provide protection against Sfi21-type phages, including $\kappa 3$ [73-74]. These systems are based on expression of antisense RNAs against genes from the replication module of the Sfi21-type phage $\kappa 3$ genome, e.g. putative primase (pri3.1) or helicase (hel3.1) genes. Strong conservation of the whole replication module among the already sequenced Sfi21-type phages makes it a good target for inhibiting phage development [73]. Moreover, hybridization studies revealed that the Sfi21-type replication module is commonly encountered in majority of industrially isolated phages. This reinforced the choice to use it as a phage defense element $[73,75]$.

To test the efficiency of the Sfi21-type module antisense RNA system, constructs expressing antisense RNA cassettes of different length were introduced into S. thermophilus strains, which were then challenged with phage infection. The most effective were constructs expressing antisense RNA covering the whole region of target (primase or helicase gene). Also shorter RNAs provided sufficient phage resistance, which was speculated to be due to the presence of specific structural or potential regulatory domains within these fragments. Furthermore, in case of constructs harboring antisense RNAs of similar length, more efficient were usually those comprising the RBS (ribosome-binding sequence) sites. Such effect was believed to be due to the fact that the antisense RBS sequences prevented gene translation by impeding efficient loading of ribosomes onto phage mRNAs [72]. Overall, expression of phage antisense RNAs in $S$. thermophilus was shown to interfere/delay the intracellular phage DNA replication, decrease phage plaque formation (EOP, efficiency of plating), lower the abundance of phage sense mRNA transcripts and reduce phage progeny particles released from infected cells [73,75].

Similar systems were also developed in Lactococcus lactis by expressing anti-sense RNAs directed against various phage genes (e.g. P335-type gp18C and $g p 24 \mathrm{C}, g p 15 \mathrm{C}$ alone, or putative replication genes, 936-type phage F4-1 major coat protein ( $m c p$ ) gene) [76-79]. In these cases, similarly as for $S$. thermophilus systems, the most efficient antisense RNAs in inhibiting phage development were those comprising the RBS site.

Current data allow to conclude that the most effective antiRNA-based phage defense systems, apart from some exceptions, are those which target: (i) genes vital for phage development (e.g. involved in synthesis of phage DNA), (ii) preferably early-expressed phage genes, (iii) genes expressed at low levels, (iv) genes which respective transcripts are unstable $[73,79]$. Sequencing of novel phage genomes and development of comparative genomics allows identification of other conserved phage genome regions that could serve as potential targets of antiRNAs.

\subsubsection{Origin-derived phage-encoded resistance}

Defense systems that employ elements derived from lytic phage genomes are termed phageencoded resistance (PER). One type of engineered PER systems is based on the origin (ori) of 
phage replication [71]. The principle of such systems relies on presenting in trans false targets (in this case, phage-derived oris), which titrate phage replication factors and make them inaccessible for the phage. In result, phage development is inhibited due to arrested replication of its DNA. These engineered systems resemble the naturally-occurring abortive infection mechanisms as they exploit the same principle (for details see: 6.4. Phage abortive infection systems).

One of the first phage origin-derived systems developed was for Lactococcus lactis and employed the ori of replication of an industrial phage $\Phi 50$ (ori50) [80]. Introduction of the $\Phi 50$ ori region on a high copy number plasmid into the L. lactis NCK203 strain provided resistance to not only to phage $\Phi 50$ itself, but also to other small isometric phage isolates from industrial environments [80-81]. It was suggested that all of these sensitive phages are part of the same family and most probably exhibit significant homologies within their ori regions. Additionally, replication of the ori50 $0^{+}$plasmid was shown to be stimulated by $\Phi 50$ infection, implying that phage factors are engaged in the process [80]. Further studies determined that the system affects neither adsorption nor phage DNA injection, which suggested that this defense mechanism acts at a later stage of phage development, i.e. DNA replication. It was also clear from the study that the origin-derived phage-encoded resistance phenotype was strongly dependent on the plasmid copy number. Most probably, low copy number plasmids are insufficient in providing enough phage ori sites that could efficiently titrate and attract phage replication factors. Yet, on the other hand, when the copy number of ori $^{+}$plasmids exceeded a certain level, resistant phage mutants were observed as a side-effect. Characterization of these mutants by DNA restriction analysis revealed mutations within the ori region, which enabled them to escape the phage defense system.

More recently, a similar origin-derived phage-encoded resistance system was developed for S. thermophilus strain Sfi1 based on the ori of phage Sfi21 [82]. The presence of this nonencoding phage DNA fragment rendered the Sfi1 host strain resistant to the concomitant phage infection by Sfi21 and 17 other S. thermophilus phages. Interestingly, all of them were found to exhibit homology within the ori region. However, resistant phages that could overcome this defense mechanism were also detected. They, on the other hand, exhibited differences in the ori sequence compared to the wild-type Sfi21-like ori. Examination of other S. thermophilus phage genomes $(\sim 30)$ allowed identifying other distinct replication oris and to divide them into separate groups: replication group I, IIA and IIB [83]. Plasmid constructs harboring these three phage ori types increased phage resistance in certain host backgrounds. However, in some strains this origin-derived phage-encoded resistance was not observed. It is therefore speculated whether the efficiency of these systems could be also dependent on some still undetermined host factors.

Development of analogous systems for other lactic acid bacteria involves identification and functional characterization of ori regions of their respective phages. This approach can be especially useful for phage-sensitive strains for which other plasmid-encoded defense systems have not yet been determined. 


\subsubsection{Superinfection immunity and exclusion}

During the lysogenic life cycle of temperate phages, the lytic module is inactive due to the activity of the CI repressor. However, certain prophage genes - the superinfection-immunity (CI-like repressor) gene itself and the superinfection-exclusion gene, are actively expressed. Both functions were determined to provide protection to the lysogenic host against phage superinfection. Application of these genes to create engineered phage defense systems is yet another strategy of protecting bacterial cells from incoming infections. Multiple bacterial genomes carry prophage-derived sequences, which can count up to $10 \%$ of the total genomic content of the cell. Therefore, despite the fact that phage-related sequences are a burden for bacterial cells, they are also believed to provide some advantage to the host by increasing its fitness.

Genomic studies in $S$. thermophilus led to the identification of superinfection-immunity (orf127) and superinfection-exclusion (orf203) genes from the lysogeny module of the Sfi21 prophage [84-85]. Expression of S. thermophilus phage Sfi21 orf127 gene from a plasmid vector conferred the phage resistance phenotype against homologous phage, but was ineffective against other heterologous phages [86]. Analysis of the respective ORF127 product revealed its structural homology with phage $\lambda \mathrm{CI}$ repressor and amino acid homology (15\% identity) to a potential CI-like repressor of the lactococcal phage Tuc2009. Gel shift experiments allowed determining the ability of the Sfi21 CI-like repressor to bind to two operator sites identified in the genome of the superinfecting homologous phage Sfi21. Superinfection immunity genes (CI repressors) were also identified in phages of other lactic acid bacteria species (e.g. for Lactococcus phage TP901-1 and Lactobacillus phages A2 and Фadh) [87-89]. Their expression in trans was also reported to provide immunity against homologous phage infection.

In contrast, superinfection exclusion genes are not engaged in maintaining the lysogenic state, yet are also active during the lysogenic cycle. Experiments based on expression of the S. thermophilus phage Sfi21 orf203 gene in trans in high copies determined that it confers resistance to superinfection of a range of heterologous lytic streptococcal phages [85]. Contrarily to the Sfi-21-derived superinfection immunity, in this case resistance to the Sfi21 phage itself was not observed. Moreover, the mechanistic background of the orf203dependent resistance phenotype was shown to involve inhibition of phage DNA injection.

A superinfection exclusion system was also developed in Lactococcus lactis based on the siezo09 gene from the temperate phage Tuc2009 [30]. When cloned in trans, siezong provided resistance only to some 936-type phages used in the study. Moreover, neither c2- nor P335type phages were affected. It was determined that Siezoog is a cell membrane-associated protein interfering at the stage of phage DNA injection. However, the exact mechanism by which Siezo09 acts was not yet established. The ability of the designed system to confer resistance only to certain 936-type phages might indicate different mechanisms of DNA injection exhibited by various phages. A similar membrane protein was detected for $S$. thermophilus phage TP-J34, Ltp. Expression of the ltp gene provided protection against TPJ34 in S. thermophilus and, interestingly in L. lactis against a 936-type phage, P008 [32]. This, 
quite surprising observation of sie-encoded cross-resistance was argued to be due to a recent genetic transfer event between the two species. In both cases, it was noted that phage adsorption was not impaired, but there was significant inhibition of phage DNA accumulation within the host cell. Based on these observations it was proposed that the ltp gene product acts at the stage of phage DNA injection by either impairing insertion of the phage tail into the cytoplasmic membrane or by obscuring the host membrane protein responsible for inducing the release of phage DNA from the capsid.

Putative superinfection exclusion genes seem to be widespread among prophage-containing lactococcal and streptococcal strains and localized in the same genomic region limited by repressor and integrase gene from each side. Although sie genes lack significant homology, all currently identified Sie proteins are small with hydrophobic $\mathrm{N}^{\prime}$ tail and at least one transmembrane domain. Various studies of lactococcal Sie proteins allowed grouping them into several phylogenetic groups, depending on the subset of 936-type phages they target (sk1/jj50, bIL170/p008 or 712 group) [28]. At present, it is argued that all sie systems identified for lactococcal lysogenic strains interact or mask cell membrane associated factors engaged in phage DNA injection or come into direct contact with structural proteins of the infecting phage. The most probable theory is that Sie function is aimed against the tail tape measure protein (function implicated in phage DNA injection process), as its encoding region is among the few divergent genomic regions between the different subsets of 936type phages.

Superinfection exclusion and immunity genes in natural conditions can also be provided by defective prophages. The nature of defective phages is that they cannot be efficiently induced by environmental factors; hence, cured from the host strain. Such lysogenic lactic acid bacterial strains (particularly Lactobacillus species), which exhibit no threat to the fermentation processes due to uncontrolled prophage induction, are of special interest to the dairy industry as naturally-resistant strains to superinfection events.

\subsubsection{Phage-triggered suicide systems}

Phage-triggered suicide systems rely on expression of toxic elements under the strict control of phage-inducible promoters. Such specifically engineered systems most closely resemble the naturally-occurring abortive infection systems, which trap the phage within infected cells and lead to programmed cell death. Upon phage infection, host cells are lysed, disabling at the same time phage propagation and the concomitant spread of the phage. In effect, the uninfected bacterial population is saved (for details see: 6.4. Phage abortive infection systems). Suicide systems are based on three genetic components: (i) a lethal gene cassette, (ii) a phage promoter induced only after phage infection, and (iii) an appropriate vector, providing sufficient amount of the lethal gene product.

Such system, based on an inducible plasmid strategy, was created for L. lactis to control phage infections [90]. The system comprises a lethal three gene cassette, llaIR ${ }^{+}$, encoding a restriction endonuclease of the L. lactis LlaI R/M system, cloned under the tight control of 
the phage $\Phi 31$ middle-expressed promoter $(\Phi 31 p)$ that is active at a significant level solely after $\Phi 31$ infection [91]. Expression of this plasmid-encoded suicide system was designed to restrict unmethylated host and phage DNA upon infection. During infection, induction of the llaIR $^{+}$cassette caused a significant drop of phage $\Phi 31$ EOP. Only a small fraction of infected cells produced progeny phage particles. The system provided also protection against other $\Phi 31$-like phages. Yet, despite the observed inhibition of phage development, some phages were found to escape this defense system. Phage mutants that emerged during the assays were all found to be altered in the sequence encoding the transcriptional activator of the $\Phi 31 p$ promoter [92]. Thus, these mutants escaped the system due to lack of efficient transcription of the $l l a I R^{+}$cassette. The drawback of this system is the fact that it is only active against phages that can trigger the phage-derived promoter; in this case, against $\Phi 31$ and its closely related phages. Another disadvantage is the fact that the llaIR cassette is not expressed immediately, but after a time necessary for the infecting phage to synthesize transcription factors activating the middle-expressed promoter. This, in effect, allows for replication of a low number of phage particles that escape restriction. It would seem more appropriate to use early phage promoters; yet, these are usually host-controlled. Improvement of the efficiency of the already existing suicide systems should involve cautious selection of effectively controlled and adequately strong phage promoters and more proficient restriction endonucleases. This is best illustrated by the described earlier observation that application of a stronger promoter, despite a more efficient reduction of phage EOP, can have a negative effect on bacterial cell growth. As a method to enhance the efficacy of the suicide system, it was proposed to include within the suicide cassette another gene - IlaIC, encoding a regulator protein [93]. The presence of this regulator protein was suggested to significantly increase the anti-phage restriction activity of LlaIR.

\subsubsection{Subunit poisoning}

The subunit poisoning system is an engineered phage defense strategy that relies on expression in trans of truncated/mutated proteins which impair (poison) the function of their wild type variants. To achieve this, mutant proteins should be expressed at levels higher than their wild-type counterparts. Moreover, despite alterations in their amino acid sequences, they must have an intact structural form in order to titrate sites or substrates, or other protein components, away from the wild-type proteins.

An example of such system is based on the CI-like repressor of lytic Lactococcus lactis phage $\Phi 31$. The general idea of this strategy resembles very much the superinfection immunity approach, where $S$. thermophilus bacteria expressing the phage Sfi21 CI repressor were protected from closely-related phages (for details see: 6.6.3. Superinfection immunity and exclusion). However, in this case, the exact mechanism is somewhat different [94]. Studies of the wild type CI repressor of phage $\Phi 31$ showed that it is non-functional and, when expressed in the L. lactis host, does not provide protection against superinfecting phages nor represses the transcription of phage lytic genes. Yet, when this wild-type $\Phi 31 \mathrm{CI}$ protein or its truncated variants were expressed in trans, they could efficiently inhibit infection of Ф31 
and other lytic P335-type phages. Expression of $\Phi 31$-derived $c \mathrm{I}$ mutant genes from a highcopy number vector was shown to inhibit growth of $\Phi 31$ (to EOP $10^{-6}$ or lower, depending on the mutation) and of other lytic P335-type phages. The observed effect was determined to be due to the competitive binding of the non-functional $\Phi 31 \mathrm{CI}$ and phage-expressed CI repressors to two of the three wild-type operators identified within the genetic switch region. It was suggested that the truncated variants of the $\Phi 31 \mathrm{CI}$ repressor exhibit a higher affinity for these sites than the phage-encoded CI protein. In effect of $\Phi 31$ CI binding, expression of lytic phage functions was repressed, impairing phage DNA replication.

During the study resistant phages were also detected. Sequence analysis studies within the genetic switch regions revealed alterations in their operator sites, which impaired binding of the $Ф 31$-derived CI repressor.

Another example of subunit poisoning phage defense is a system developed in Streptococcus thermophilus. The strategy was based on mutating the primase-encoding gene, an essential component of the replication module of the S. thermophilus Sfi-21-like $\kappa 3$ phage [95]. Mutation of sequences within the highly conserved domains of the primase gene resulted in obtaining dysfunctional protein variants. Expression at high level of such primase derivatives in trans resulted in reduction of EOP of $\kappa 3$ and several other Sfi-21-type phages due to inhibition of phage DNA replication. The mutated primase was implied to titrate replication factors and/or the origin of replication, making them inaccessible for the wildtype primase. This suggestion seems to be credible as introduction of the STOP codon upstream of the initial gene mutations restored the phage sensitivity phenotype. Such alteration lead to the synthesis of a truncated protein, which, most probably, could no longer mimic the structure of the native primase. A great advantage of this primase-based subunit poisoning system is lack of phage mutants resistant to the mutated primase proteins under study.

Overall, subunit poisoning is an approach that is believed to constitute a broad phage defense system, as it was shown to be effective against more than one lytic P335-type phage. In this aspect, it differs from the earlier described superinfection immunity systems, where expression of phage repressor genes from phages of various lactic acid bacterial species (e.g. Streptococcus phage Sfi21, Lactococcus phage TP901-1 or Lactobacillus A2 or Фadh phages) provided immunity against the respective single phage only [85,87-89].

\subsubsection{Host-factor elimination}

Eliminating a genetic element from the genome of starter bacteria to obtain phage-resistant strains is yet another strategy of engineering a phage defense system. This approach can target different stages of the phage life cycle, which are often host-dependent, e.g. phage injection dependent on host membrane proteins, host factors necessary for phage DNA replication.

Among methods identifying such host-encoded factors is random mutagenesis using the pGhost::ISS1 mutation vector. This approach allowed to identify genes necessary for phage 
development in the genome of the S. thermophilus Sfi strain [96]. The orf394 gene, encoding a putative transmembrane protein, was one of the host loci determined to confer phage resistance to Sfi19 as well as more than 10 other heterologous S. thermophilus phages. After infection by phage Sfi19, no phage DNA synthesis was detected for such mutant strain. Based on this observation, it was suggested that this transmembrane protein may be implicated in the stage of phage DNA injection, analogously to the Pip (phage infection protein) of Lactococcus lactis [97]. Among advantages of the host-factor elimination system is the fact that it is food-grade and that the engineered phage resistant strains can be successfully used in production processes. Yet, it must be noted that before its application in the industry, the strain should be assayed for its phage resistance phenotype during several rotation rounds of culturing. There is also no data on the phage mutants that can evolve due to the continuous use of such Pip- mutant strains.

Other host factors that were suggested to be efficient targets for developing phage defense systems are auxotrophic genes. Pedersen et al. developed a strategy of impairing phage replication in an industrial Lactococcus lactis strain by deleting the thymidylate synthase $($ thy $A)$ gene from its genome [98]. This patented strategy is based on the process of phage DNA replication [99]. Upon infection, phages take advantage of the DNA replication machinery of the host to amplify its own genetic material. However, when the host is lacking one of the main DNA building factors, formation of novel replicated DNA molecules is inhibited. The thyA gene is responsible for de novo synthesis of dTTP in the cell. Strains devoid of thy $A$ cannot synthesize dTTP in the medium that lacks thymidine, such as milk. Under such conditions, the $\triangle$ thy $A$ mutant was resistant to infection by selected P335- and 936-type phages, which efficiently infected the parental wild type strain, and what is important its acidifying properties remained undisturbed. Addition of thymidine to the milk medium restored phage sensitivity of the strain. Among the drawbacks of this system is the fact that the mutant strain lacking thymidylate synthase is impaired for growth. Therefore, in industrial conditions it must be inoculated into milk tanks at higher concentrations than the parental wild type strain in order to meet the technological criteria. A solution to this problem could be addition of limiting amounts of thymidine to promote growth of such starter strain. Yet, thymidine as an additive in the cheese industry is not allowed. Among various options proposed by Pedersen to obtain a phage-resistant thy mutant for industrial use could be construction of a thermosensitive mutant, in which expression of the thy gene is inhibited at temperatures at which technological processes are carried out [98]. The greatest concern when selecting for phage-resistant strains is their ability to prevail a broad range of phages over long periods of time. In this case, it seems that the host-factor elimination system is the most universal among the presented systems as it acts against all phage types. Moreover, at this point it seems that the probability of occurrence of phage mutants overcoming this resistance mechanism is low. However, it should also be noted that some phages are known to encode own thy genes or utilize nucleotides of the host by hydrolyzing its DNA, which can be a weak point [100-101]. 


\section{Problem of phage contamination in dairy industry}

There are no commercial LAB cultures available which would be completely insensitive to all phages. Even when a starter culture that is launched on the market appears to be phage resistant, phages are detected usually after a certain period of use.

Phage contaminations in dairy plants can cause 3 main serious drawbacks:

- problems in obtaining expected technological parameters and product quality consistence

- $\quad$ staff stress, decrease of motivation and engagement, irregular working hours, staff economical consequences, job resignation

- financial losses (failed production, non-standard product, lower unit price, delayed deliveries, customer losses).

\section{Phage detection in dairy industry}

\subsection{Simple tools for phage detection at the dairy plant level}

A simple test assessing acidification activity of currently used starter cultures on a daily basis can be used successfully to monitor phage contaminations in dairy plants. Briefly, a cheese whey sample from the last production vat of the shift is collected and, before use, sterilized by filtration $(0.45 \mu \mathrm{m}$ filter-pore size). In the case of dairy beverages, a sample of the final product, before its filtration, is clarified with addition of lactic acid and centrifuged. Processed pasteurized milk or sterilized milk reconstituted from powder is inoculated in duplicate with starter cultures (including a phage alternative culture) at a standard dosage. One sample of each culture is inoculated with a whey filtrate (usually 1-2\%) and the second one - with a temperature sterilized whey filtrate. After incubation (the temperature and time depend on the culture and process), the $\mathrm{pH}$ of the milk is measured. When the $\mathrm{pH}$ of the milk containing the filtrate is 0.2 units higher in comparison to the sample containing the sterilized filtrate, it indicates that phage contamination is rather high and phage-unrelated culture rotation as well as disinfection with higher concentrations of active substances should be recommended.

To avoid direct measurements of $\mathrm{pH}$, bromocresol purple $\left(100 \mu \mathrm{g} \mathrm{ml}^{-1}\right)$ as a $\mathrm{pH}$ indicator may also be used. The test lasts around $6 \mathrm{~h}$, for mesophilic starters, and $4 \mathrm{~h}$, for thermophilic cultures. When $\mathrm{pH}$ of the milk drops below 5.4, the indicator turns from purple to yellow. If, at the same time, the color of the sample containing the non-sterilized filtrate becomes green or purple, it means, with high probability, that phages are present and may adversely influence the fermentation process [102].

Another approach of phage detection is continuous monitoring of $\mathrm{pH}$ during fermentation processes conducted in vats or tanks with short time intervals and plotting the data on a graph. Even in the case when delay of the fermentation process is not observed, but the graph shows an irregular shape not related to temperature deviation, phage contamination 
is suspected (Fig.1). However, in this method a delay in acidification can also result from other inhibitors than phages (e.g. antibiotics, detergents) present in the sample.

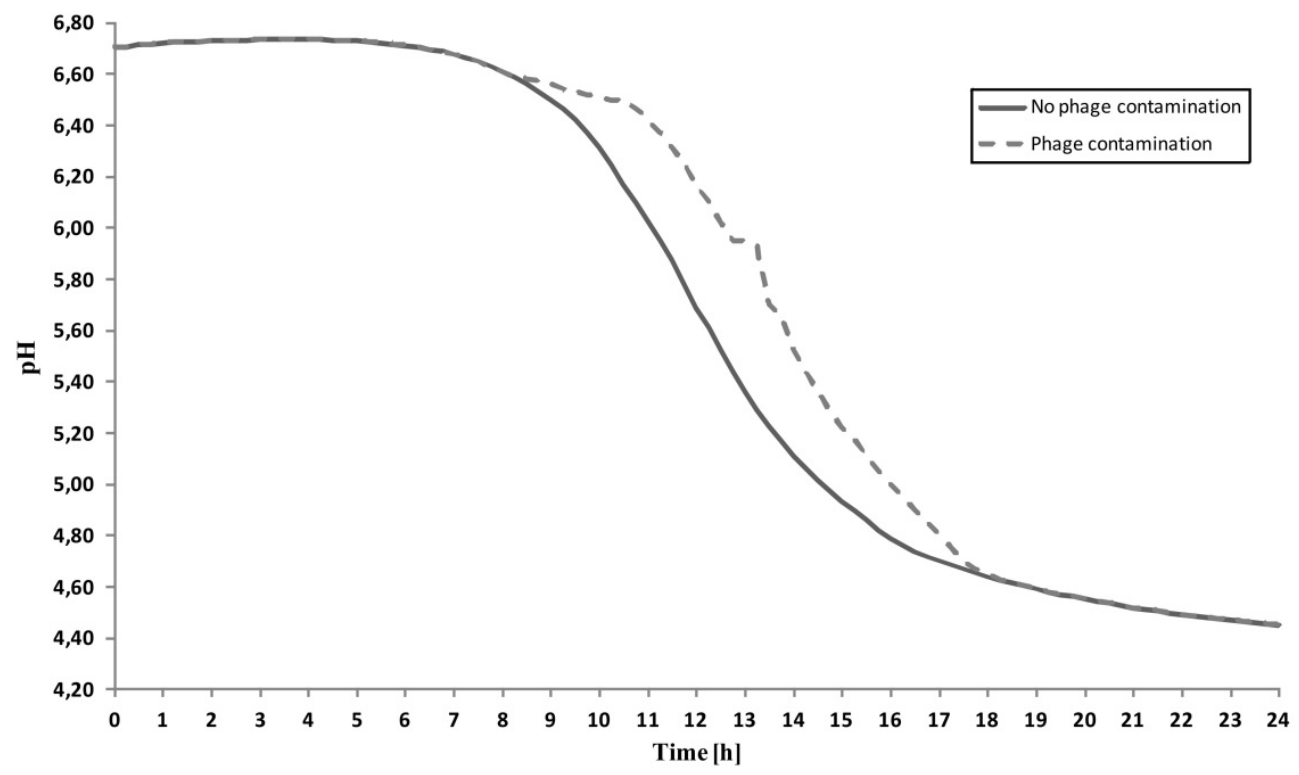

Figure 1. Example of $\mathrm{pH}$ curve during milk fermentation in the presence of virulent phages incubated with the multistrain and multispecies culture.

\subsection{Routine service at culture supplier level}

The most common and most useful method of phage enumeration is the plaque assay. The method is quite old and was first described by d'Herelle shortly after the discovery of bacteriophages. Currently it is used in many labs with some modifications, but its principle has not changed [103]. The most common, practical, cheap, without using large numbers of plates and sufficiently accurate method in the dairy industry is the semi-quantitative spot test method. Using this approach, results are available after $24-48 \mathrm{~h}$. The method is well suitable for detection of phages of pure lactic acid bacterial strains at relatively low levels (< 100 phages $\mathrm{ml}^{-1}$ ). Plague assays allow detecting the presence of phages as well as determining the number of phages in dairy samples against all individual strains present in the applied defined cultures. In case of phage contamination in a dairy plant, the method is a good tool for selecting the best phage-resistant alternative cultures. The method can also be used for hygiene monitoring by enumeration of phages in samples collected from critical places if the plant. For dairy culture producers, permanent phage monitoring can identify strains which are most sensitive in defined cultures. These strains can be systematically replaced with more phage resistant strains. Semi-solid medium supporting 
bacterial growth is used for multiplication of strains in form of a smooth opaque layer or lawn on the medium surface using standard Petri dishes. Serial dilutions of phage solution previously sterilized with a filter are placed (5-20 $\mu \mathrm{l})$ on the surface of the opaque layer. When a single phage particle develops on a recipient bacterial lawn, it forms a plaque (clear spot, no bacterial lawn) visible to the naked eye. This plaque results from the destruction of bacterial cells by the phage progeny. Growth of the plaque is limited by slow diffusion of the phage in the semi-solid medium and bacterial cell growth stops, so phage growth is also inhibited due to the fact that host cells support phage growth. No visible plaques on the plate mean that the sample is not contaminated by phages. Large clear zones (no separate plaques) on the plate indicate with high probability that the level of phages is rather high and further dilutions of the sample are required to precisely determine the phage titer. The presence of a plaque means that: i) the tested sample contains phages; ii) the phage is virulent against the tested strain; iii) the strain is sensitive to the phage. Each phage particle that gives rise to a plaque is called a plaque-forming unit (PFU). One plaque corresponds to a single phage particle and phages can easily be counted. In result, the number of PFUs corresponds to the viable phage concentration in a given sample volume.

\subsection{Sensitive methods (including ELISA and molecular DNA techniques) at the level of academic or innovation labs}

Plaque assays and acidification tests are microbiological methods that are economically accessible and sensitive enough for detection of phages in the dairy industry. These techniques are time consuming, but provide many practical data for both dairy plants and starter producers. The polymerase chain reaction (PCR), ELISA and flow cytometry-based methods have been designed for detecting phages and are often used to complement microbiology tests. However, they have still many drawbacks to be applied for routine analyses in the dairy industry [104].

PCR-based methods detect virulent and non-virulent phages; thus, microbial methods should be used in parallel to precisely distinguish the virulent phages. PCR-based methods can also be too expensive and too specific (only phages targeted by specifically-designed primers are detected) for routine experiments. However, PCR is a fast method able to confirm the presence of bacteriophages within 30 minutes and can be applied to determine the potential utility and quality of big batches of milk. At the same time, the method could be handy in finding niches of phage accumulation, in order to reduce their impact in dairy fermentations [105-108].

ELISA techniques use for phage detection antibodies which are highly specific against structural proteins of phage capsids. Due to the wide phage diversity in the dairy environment, development of several antibodies detecting various groups of phages was required. ELISA is regarded as a highly useful method for monitoring specific phages in the dairy environment, but a single assay cannot be used to detect phages with different 
structural proteins. For this reason, the sensitivity of an ELISA method to detect phages in dairy a sample is rather low.

Flow-cytometry can also be used for detection of phages in dairy samples by discriminating the phage-infected cells from non-infected based on cell morphological changes leading to lysis. Running on the flow-cytometry of samples containing phages gives a broad distribution of cell mass (wide peak), which demonstrates the presence of both lysed and live cells, while non-infected samples give narrow peaks. Flow-cytometry allows detection of phages in real time, but expensive equipment and well-trained staff needed to perform the assays limits application of this technique in the dairy industry [104].

\section{Sources of phage contamination}

In dairy plants phages can originate from a variety of sources. The prime importance is to identify the potential sources of phage contamination and limit their entry to the fermentation process.

\subsection{Raw milk}

The most probable source of virulent phages is raw milk. LAB phages occur naturally in raw milk at low titers (between $10^{1}-10^{3} \mathrm{PFU} \mathrm{m} \mathrm{ml}^{-1}$ ) and constitute a continuous supply of bacteriophages in dairy plants [109-110]. Phage concentrations in raw milk also depend on conditions of collecting, handling and storing of milk by the supplier (farm), on transport to the plant and, finally, handling of the milk in the plant itself. For example, reverse osmosis used to concentrate raw milk at a farm can impact the level of phages detected in milk. Almost $10 \%$ of 900 milk samples examined from various geographical areas in Spain contained Lactococcus lactis phages [110]. Using a multiplex PCR method Streptococcus thermophilus phages have been detected in more than one third of milk samples used for yoghurt production in Spain [106]. Phage biodiversity is increased by combining milk collected from different farms and these numbers can be even higher in processed milk.

\subsection{Milk powder and whey protein concentrates}

Reconstituted milk from powder is used in many countries for yoghurt, fresh cheese (tvarog and quark) and even maturated cheese production. Also whey proteins are used to standardize milk before the fermentation process or to improve the taste and texture as well as the nutrient value of the final product. Recently, the modern technology of milk powder and whey protein concentrate production applies often lower temperatures of treatment than during traditional technologies. Both milk powder and whey protein concentrates can be sources of high temperature-resistant phages and can influence the quality of the final product [111-112]. For separating whey proteins, ultrafiltration or/and microfiltration are more frequently employed. Applied separation processes result in higher concentrations of phages in the permeate or the retentate. Depending on which fraction is used in subsequent processes, different concentrations of phages in whey protein samples can be detected. 


\subsection{Starter cultures}

The starter culture itself can be a source of phages, when strains contain temperate phages. Temperate phages are incorporated into the bacterial chromosome and their genome replicates in synchrony with the bacterial genome. Prophages are carried in many LAB strains. The analysis of bacterial genomes revealed that prophages are more widespread than previously considered [113-114]. Phages may be induced from lysogenic to lytic form by the manufacturing conditions. Serial subculturing of temperate phages in milk may result in their replacement by a virulent mutant. Prophage induction from multiple lysogenic starter culture strains has the potential to influence fermentation. Induction can occur under stress conditions, such as heat, salts, acidity, bacteriocins, starvation or UV [115$116]$, and can also occur naturally with a frequency of even up to $9 \%$ [117]. Starter culture producers make huge efforts to eliminate strains containing prophages using a screening assay for strain lysogeny. Usually, easily lysogenized strains are difficult to find in defined strain cultures. The main source of lysogenic strains are undefined cultures, which are still commonly used (for example, kefir grains). This is due to two main reasons: i) the exact strain composition of these starters is unknown; ii) elimination of lysogenic strains from undefined culture is very difficult.

\subsection{Equipment/air}

The one of the most probable sources of virulent phages is the dairy plant environment. Phages are commonly present on working surfaces. For propagation, phages need the presence of their bacterial hosts, in this case lactic acid bacteria. Due to this fact, they are usually found in places where conditions for LAB development are favorable. The most common sources of phage contaminations are valves, crevices and "dead ends" (difficult cleaning and disinfection places) of production lines. Also, the formation of biofilms on dairy equipment can lead to serious phage problems. Moreover, phages were detected at high levels on various equipments and objects found in cheese plants, such as walls, pipes, door handles, floors, office tables and even on cleaning materials [118]. Raw milk handling, cheese milk processed in open vats and whey handling can lead to spreading of phages in the air. Phage aerolization can occur during air displacements around contaminated places (fluids or surfaces) or by liquid splashes. Virulent phages can circulate through the air far away from their aerosolization source due to the ability to bind to small particles $(<2.1 \mu \mathrm{m})$ [118]. Taking into account high levels of phages detected in the air, it is hard to precisely determine whether phage propagation already took place or if it is likely to occur. Concentrations of up to $10^{8} \mathrm{PFU}$ per $\mathrm{m}^{3}$ of air have been detected in a cheese manufacturing plant in Germany; however, mainly in specific areas of the fermentation line [119-120].

\section{Phage problem frequencies and consequences depend on product portfolio}

Fermentation problems in the dairy plant can be related with: low starter activity, fermentation conditions (e.g. temperature fluctuations), milk composition (year, season, 
occurrence of mastitis, mineral levels, lactation period, microbial and enzymatic composition), presence of inhibitors in milk (antibiotics, detergents) and phage infections.

However, phages are the primary source of fermentation problems in the dairy industry. Bacteriophages can cause great economic losses due to fermentation failure in dairy plants. About one third of the annual world production of around 500 million tons is converted into fermented products. Two thirds of all processed milk is fermented by Lactococcus lactis and Leuconostoc spp. Thermophilic Lactobacillus and Streptococcus thermophilus spp. account for fermentation of the remaining major part of the milk. According to estimations, from $0.1 \%$ to $10 \%$ of all milk fermentations are negatively affected by virulent phages [102]. Phage contaminations can slow down or even halt the milk fermentation process. Consequences of the phage presence include: alteration of the product quality, such as taste, flavor, texture, and its microbiota composition. Phage contaminations due to the delay in lactic acid production can also lead to development of undesired microbiota during the fermentation process. In the worst cases, the inoculated milk must be discarded. The frequencies of phage contaminations and their consequences depend on the type of milk product produced. Phages can also sometimes turn a dairy staff life into a 'nightmare'.

\subsection{Fermented milk beverages}

Among dairy products, the least phage affected are fermented milk beverages (yoghurt, kefir, butter-milk, Actimel®-like products, etc.). There are many reasons behind this phenomenon. Milk for beverage production usually undergoes treatment at temperatures much higher than in cheese manufacturing. Moreover, some drinking yoghurts are produced from UHT milk. Beverages are made in relatively aseptic conditions, including more and more aseptic inoculation systems, where the fermented product is minimally exposed to the factory environment. In spite of that, phage contamination is sufficiently frequent and has become the primary source of fermentation problems in milk beverage production. Phage contaminations in this particular case lead to fermentation delays or inhibition, product alterations in taste and flavor as well as texture properties.

\subsection{Ripened cheese}

In cheese production the risk of phage infection is very high. A large cheese plant can process more than 500 tons of milk per day, very often in many vats, lasting more than one shift. Pasteurized milk (very often low temperature-treated milk or even raw milk) is used in cheese fermentation and many phages as well as microorganisms remain viable after pasteurization. Contamination, also by phages, increases during curd handling and whey separation in open vats. The consequences of phage infection in cheese production can be: delay or halt in milk acidification, cheese contamination with foreign microbiota, including pathogens, preferential growth of post-pasteurization microbiota, problems in whey separation (syneresis), higher water and lactose content in the final cheese product, abnormal or irregular holes (eyes), or no eyes, and alterations of flavor and texture [5]. To conclude, phage contamination may result in lower quality of cheese or cheese 
quality suitable only for processed cheese production and, in some extreme cases, complete loss of product.

\subsection{Fresh cheese (cottage cheese, quark, tvarog)}

Cottage cheese and traditional tvarog productions are the most sensitive processes to phages infection. Fermentation delays in production of cottage cheese lead often to complete loss of the final product. However, symptoms of phage contamination are most visible in production of traditional tvarog, where curd quality depends on the activity of lactic acid bacteria alone (rennet is not used). It is estimated that more than $70 \%$ of technological disruptions during tvarog manufacture is related to phage contaminations, which usually lead to the following consequences: delay or halt in milk acidification, curd lamination or its drop to the bottom of the tank or vat (which, in effect, causes problem with curd handling), prolonged process of whey separation due to the loss of the curd syneresis, low tvarog yield, contamination with foreign microbiota, including pathogens, intensive growth of postpasteurization microbiota, off-flavor and texture alterations of the tvarog [121].

\section{Phage control strategy}

As previously stated, phages represent a constant threat of serious economic losses in the dairy industry. Dairy microbiologists have attempted for almost 80 years to eliminate or, at least, bring under better control, bacteriophages that interfere with the manufacture of fermented milk products. Phages rapidly disseminate in dairy environment and are difficult to eliminate. The important procedures for phage control are: adapted factory design, design of starters, cleaning and disinfection, and air control [102].

\subsection{Cleaning and disinfection}

The classical operations of cleaning and disinfection are an essential part of milk processing. Cleaning-in-place (CIP) procedures are usually applied in milk processing lines. The basic procedure consists of the following sequence operations: i) pre-rinse with cold water to remove gross residues; ii) circulation of alkali detergent to remove the remaining minor residues (from time to time acidic detergent is incorporated to remove precipitated minerals and milkstone deposits in the following sequence: alkali detergent, water rinse, acidic detergent); iii) rinse with cold water to flush out the detergent; iv) circulation of disinfectant to inactivate residual microorganisms and phages (still in many dairies this stage is not performed in each cleaning cycle); v) final rinse with cold water to flush out the detergent and cooling line [122]. The cleaning process can remove $90 \%$ or more of microorganisms associated with the surface, but cannot kill all of them. One of the drawbacks of the cleaning process is that residual live bacteria can redeposit and, in longer periods of time, can form a biofilm. The presence of $\mathrm{LAB}$ among the residual microorganisms increases phage risk contamination. The main role of disinfection is to kill microorganisms that survive the cleaning procedures. 


\begin{tabular}{|c|c|c|c|c|c|}
\hline \multirow{2}{*}{ Disinfectant } & \multirow{2}{*}{$\begin{array}{l}\text { Supplier/ } \\
\text { Producer }\end{array}$} & \multirow{2}{*}{$\begin{array}{l}\text { Main active } \\
\text { substances }\end{array}$} & \multicolumn{3}{|c|}{$\begin{array}{l}\text { Conditions recommended by } \\
\text { supplier }\end{array}$} \\
\hline & & & $\begin{array}{c}\text { Concentration } \\
(\%) \\
\end{array}$ & $\begin{array}{l}\text { Temp. } \\
\left({ }^{\circ} \mathrm{C}\right)\end{array}$ & $\begin{array}{l}\text { Time* }^{*} \\
(\min .)\end{array}$ \\
\hline Deptil PA 5 & Hypred & $\begin{array}{l}\text { Hydrogen peroxide, } \\
\text { Peracetic acid, } \\
\text { Acetic acid }\end{array}$ & $\begin{array}{l}0.1 \text { - antiseptic } \\
2.5 \text {-fungicidal }\end{array}$ & $<30$ & 20 \\
\hline $\begin{array}{l}\text { Divosan } \\
\text { Hypochlorite } \\
\text { VT3 } \\
\end{array}$ & $\begin{array}{l}\text { Johnson } \\
\text { Diversey }\end{array}$ & Sodium hypochlorite & $0.1-3.0$ & cool & $10-20$ \\
\hline $\begin{array}{l}\text { Oxidan } \\
\text { special } 150\end{array}$ & Novadan & $\begin{array}{l}\text { Hydrogen peroxide, } \\
\text { Peracetic acid, } \\
\text { Acetic acid }\end{array}$ & $0.1-0.35$ & $5-40$ & $5-60$ \\
\hline $\begin{array}{l}\text { Hypochlor } \\
\text { DES }\end{array}$ & Novadan & $\begin{array}{l}\text { Sodium hypochlorite, } \\
\text { Sodium hydride }\end{array}$ & $0.25-1.0$ & 20 & 15 \\
\hline Desinfect CL & Novadan & Sodium hypochlorite & $0.20-1.0$ & $5-40$ & $10-15$ \\
\hline P-3 Oxonia & Ecolab & Hydrogen peroxide & $0.5-1.0$ & ca. 10 & $5-30$ \\
\hline $\begin{array}{l}\text { P-3 Oxonia } \\
\text { active } 150\end{array}$ & Ecolab & $\begin{array}{l}\text { Hydrogen peroxide, } \\
\text { Peracetic acid, } \\
\text { Acetic acid }\end{array}$ & $0.1-0.2$ & ca. 10 & $5-30$ \\
\hline $\begin{array}{l}\text { P3 - Oxysan } \\
\text { ZS }\end{array}$ & Ecolab & $\begin{array}{l}\text { Hydrogen peroxide, } \\
\text { Peracetic acid, } \\
\text { Acetic acid, } \\
\text { Peroxyoctanoic acid }\end{array}$ & 0.10 & $\begin{array}{l}\text { ca. } 10 \\
\max .40\end{array}$ & $5-30$ \\
\hline $\begin{array}{l}\text { P-3 } \\
\text { Hypochloran }\end{array}$ & Ecolab & $\begin{array}{l}\text { Sodium hypochlorite, } \\
\text { Sodium hydride }\end{array}$ & $0.2-0.5$ & $20-60$ & 15 \\
\hline $\begin{array}{l}\text { P-3 Horolith } \\
\text { CD }\end{array}$ & Ecolab & $\begin{array}{l}\text { Nitric acid, } \\
\text { Phosphoric acid, } \\
\text { Polyhexamethylene } \\
\text { biguanide hydrochloride }\end{array}$ & $0.5-1.5$ & $50-70$ & 10 \\
\hline Clarin spezial & Clarin & $\begin{array}{l}\text { Peracetic acid, } \\
\text { Hydrogen peroxide }\end{array}$ & $0.2-0.5$ & 20 & $5-20$ \\
\hline
\end{tabular}

*exposure time

Table 2. Characteristics of CIP disinfectants used in the dairy industry.

Disinfection is becoming more and more important in the current strategies used by the dairy industry to limit bacteriophage infections. The virucidal efficacy of disinfectants against bacteria, yeasts, moulds, including pathogens, is well-documented in supplier specifications, but very seldom the information on the efficacy against phages is available. It is wrong to consider that disinfectants active against bacteria will also inactivate bacteriophages [123]. The virucidal activity of commercially available disinfectants is unknown or known only against lab reference phages proposed by the established in 1989 


\begin{tabular}{|c|c|c|c|c|c|}
\hline \multirow{2}{*}{ Disinfectant } & \multirow{2}{*}{$\begin{array}{l}\text { Supplier/ } \\
\text { Producer }\end{array}$} & \multirow{2}{*}{ Main active substances } & \multicolumn{3}{|c|}{$\begin{array}{l}\text { Conditions recommended by } \\
\text { supplier }\end{array}$} \\
\hline & & & $\begin{array}{c}\text { Concentration } \\
(\%) \\
\end{array}$ & $\begin{array}{c}\text { Temp }{ }^{*} . \\
\left({ }^{\circ} \mathrm{C}\right)\end{array}$ & $\begin{array}{c}\text { Time }^{* *} \\
\text { (min.) }\end{array}$ \\
\hline $\begin{array}{l}\text { Deptil } \\
\text { Mycocide S }\end{array}$ & Hypred & $\begin{array}{l}\text { Propan-2-ol } \\
\text { Didecyldimonium chloride }\end{array}$ & $0.3-2.5$ & $\mathrm{RT}$ & 5 \\
\hline Deptil HDS & Hypred & $\begin{array}{l}\text { Ethanol } \\
\text { Sorbic acid }\end{array}$ & undiluted & RT & 5 \\
\hline Deptil BFC & Hypred & $\begin{array}{l}\text { Laurylamine } \\
\text { dipropylenediamine }\end{array}$ & 1.0 & $20-90$ & $5-15$ \\
\hline $\begin{array}{l}\text { Tego } 2000 \\
\text { VT } 25\end{array}$ & $\begin{array}{l}\text { Johnson } \\
\text { Diversey }\end{array}$ & $\begin{array}{l}\text { Amphoteric surfactants } \\
\text { (amines, N-C10-C16- alkyl } \\
\text { trimethylenedi, reaction } \\
\text { products } \\
\text { with chloroacetic acid) }\end{array}$ & $0.5-1.0$ & $\begin{array}{c}\mathrm{TR} \\
\max 50\end{array}$ & $15-60$ \\
\hline $\begin{array}{l}\text { Divodes FG } \\
\text { VT } 29\end{array}$ & $\begin{array}{l}\text { Johnson } \\
\text { Diversey }\end{array}$ & $\begin{array}{l}\text { Propan-1-ol } \\
\text { Propan-2-ol }\end{array}$ & $50-100$ & RT & $5-15$ \\
\hline $\begin{array}{l}\text { Divosan } \\
\text { Extra VT } 55\end{array}$ & $\begin{array}{l}\text { Johnson } \\
\text { Diversey }\end{array}$ & $\begin{array}{l}\text { Benzalkonium chloride } \\
\text { (CAS No 8001-54-5) }\end{array}$ & $0.4-0.8$ & $\mathrm{RT}$ & $60-240$ \\
\hline Suredis VT1 & $\begin{array}{l}\text { Johnson } \\
\text { Diversey }\end{array}$ & $\begin{array}{l}\text { Cationic surfactants (N-(3- } \\
\text { aminopropyl)-N- } \\
\text { dodecylpropane-1,3-diamine } \\
\text { CAS: } 2372-82-9 \\
\text { Sodium carbonate } \\
\text { Disodium tetraborate } \\
\text { decahydrate }\end{array}$ & $0.5-2.0$ & $\begin{array}{c}\mathrm{RT} . \\
\max 50\end{array}$ & $5-30$ \\
\hline $\begin{array}{l}\text { Tego } \\
\text { Hygiene } \\
2001\end{array}$ & $\begin{array}{l}\text { Johnson } \\
\text { Diversey }\end{array}$ & $\begin{array}{l}\text { Trisodium nitrilotriacetate } \\
\text { (CAS:5064-31-3) } \\
\text { N-Dodecylpropane-1,3- } \\
\text { diamine } \\
\text { (CAS: 5538-95-4) } \\
\text { 2-methoxymethylethoxy } \\
\text { propanol } \\
\text { (CAS: 34590-94-8) } \\
\text { reaction product of } \\
\text { alkylamino acetic acid and } \\
\text { alkyl diazapentane } \\
\text { (CAS: 139734-65-9) }\end{array}$ & $1.0-2.0$ & $\begin{array}{c}\mathrm{RT} \\
\max 50\end{array}$ & $15-60$ \\
\hline Virocid & CID Lines & $\begin{array}{l}\text { Benzalkonium chloride } \\
\text { Dimetylodidecyloammoniu } \\
\mathrm{m} \text { chloride } \\
\text { Glutaraldehyde } \\
\text { Propan-2-ol }\end{array}$ & $0.5-1.0$ & $\mathrm{RT}$ & 60 \\
\hline
\end{tabular}




\begin{tabular}{|c|c|c|c|c|c|}
\hline \multirow{2}{*}{ Disinfectant } & \multirow{2}{*}{$\begin{array}{l}\text { Supplier/ } \\
\text { Producer }\end{array}$} & \multirow{2}{*}{ Main active substances } & \multicolumn{3}{|c|}{$\begin{array}{l}\text { Conditions recommended by } \\
\text { supplier }\end{array}$} \\
\hline & & & $\begin{array}{c}\text { Concentration } \\
(\%) \\
\end{array}$ & $\begin{array}{c}\text { Temp*. } \\
\left({ }^{\circ} \mathrm{C}\right)\end{array}$ & $\begin{array}{l}\text { Time }^{* *} \\
(\mathrm{~min} .)\end{array}$ \\
\hline Eko Javel & $\begin{array}{l}\text { PUT } \\
\text { Ekoserwis }\end{array}$ & $\begin{array}{l}\text { Sodium hypochlorite } \\
\text { Sodium hydride }\end{array}$ & $0.5-1.5$ & RT & 15 \\
\hline P-3 Topax 91 & Ecolab & $\begin{array}{l}\text { Benzalkonium chloride } \\
\text { (CAS No 8001-54-5) }\end{array}$ & $0.50-1$ & RT & $10-20$ \\
\hline P-3 Topax 99 & Ecolab & $\begin{array}{l}\text { Alkyl ammonium acetate } \\
\text { Acetic acid }\end{array}$ & $\begin{array}{l}1.0 \text { - static } \\
\text { method } \\
2.0 \text { - foam } \\
\text { method }\end{array}$ & $\mathrm{RT}$ & $10-20$ \\
\hline $\begin{array}{l}\text { P-3 topactive } \\
\text { DES }\end{array}$ & Ecolab & $\begin{array}{l}\text { Hydrogen peroxide } \\
\text { Acetic acid } \\
\text { Amino-oxide }\end{array}$ & $1.0-3.0$ & RT & $10-30$ \\
\hline P-3 Monodes & Ecolab & $\begin{array}{l}\text { Benzyl alcohol } \\
\text { Propanol-2-ol } \\
\text { Ethanol }\end{array}$ & undiluted & $\mathrm{RT}$ & 0.5 \\
\hline $\begin{array}{l}\text { Anthium } \\
\text { Dioxide 5\% } \\
\text { active } \\
\text { chlorine }\end{array}$ & GSG & $\begin{array}{l}\text { Chlorine dioxide } \\
\text { Activator - citric acid }\end{array}$ & $0.01-0.05$ & $\mathrm{RT}$ & 10 \\
\hline
\end{tabular}

Table 3. Characteristics of the disinfectants for surfaces, equipment, shoe baths and hands used in dairy industry.

CEN committee for harmonizing the method of evaluating the efficacy of disinfectants [124]. Factors influencing the efficiency of a given disinfectant are: concentration, temperature and exposure time. Among them, the most important is the concentration of active substances. Most of disinfectants are less effective against phages in the presence of interfering proteins (milk or whey) or hard water. The virucidal activity of most disinfectants is improved by increasing the temperature and is usually the lowest in cold water. Therefore, at low temperatures and/or in the presence of proteins, disinfectant concentration and/or contact time should be increased. It is always advisable to combine biocides and heat rather than use them separately at extreme conditions [125]. However, no disinfectant will be fully effective when sanitized surfaces are not cleaned and proteins or biofilm-living cells are present [126]. Under certain conditions phage particles may exist as aggregates, which may also impair complete inactivation. Peracetic acid and sodium hypochlorite are the most efficient biocides of the CIP system in the dairy industry; however, literature data indicate that some LAB phages may be resistant to sodium hypochlorite [125,127-130]. Nonetheless, the most recently available disinfectants are a combination of several biocides. Table 2 presents the chemical content of CIP disinfectants and conditions of their use in the dairy industry as recommended by the suppliers. 
Disinfectants recommended mainly for surfaces, equipment, hands and shoe sanitization are listed in Table 3. Disinfectants are in liquid, foam or aerosol form, depending on their application. The efficacy of such disinfectants for phage inactivation, especially those based on alcohols, are lower in comparison to CIP disinfectants. Among biocides, particularly ineffective in phage inactivation is isopropanol [125]. However, taking into account a lower number of phages in an environment, it can be sufficient for their elimination.

\subsection{Design of starter cultures rotation system based on phage contamination control}

Starter cultures are a key factor influencing the diversity of phage population in a dairy plant. Application of undefined multispecies and multistrain cultures was the main strategy to overcome production problems related to phages in many factories (Flora Danica - Chr. Hansen, Probat 505 - Danisco) in the past. One complex culture (e.g. Flora Danica) allowed producing many products: maturated cheese, fresh cheese (tvarog and quark), butter, butter-milk and other mesophilic fermented beverages. Complex multispecies and multistrain cultures are relatively phage tolerant and even upon high phage contamination give products with small deviations that are accepted for marketing. In the past, when dairy plants produced a wide range of products, mainly for the local market, complex undefined cultures fulfilled the expectations of the dairy business.

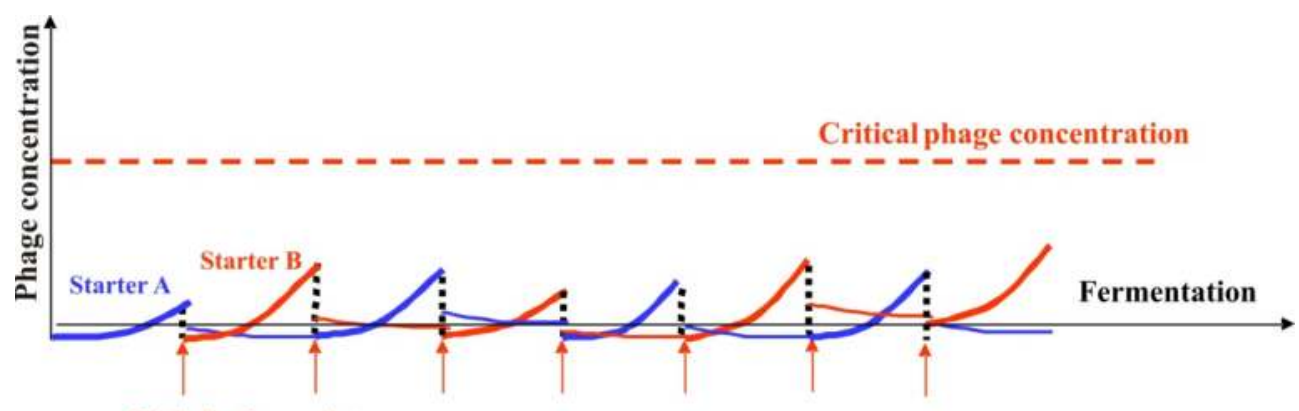

Disinfection points

Figure 2. Example of well-designed culture rotation and disinfection frequency strategy for phage control in dairy plant.

Modern industrial fermentations increasingly rely on well-defined, direct vat inoculated (DVI), high concentrated ( $>10^{10} \mathrm{cfu}^{-1}$ ) and product-optimized starters, containing from two to five phage-unrelated strains [131-132]. Market share of bulk starters (semi-direct inoculation) diminished very fast in the last two decades and does not exceeded $20 \%$ for dairy beverages and $60 \%$ for cheese of the total global processed milk. The defined cultures have been widely adapted in large-scale production facilities due to the significant degree of control over fermentation processes and complementary fermentation properties, such as rapid acidification, gas formation, texturization, and development of flavor and aroma compounds. Each defined culture is designed in two or 
three phage-unrelated options, which can consistently enable producers to obtain high quality standard products. Rotation of defined phage-unrelated cultures is an efficient phage control method. Usually the rotation strategy in big dairy plants is elaborated in tight collaboration with culture suppliers based on individual phage monitoring programs. Ideally, sterilized products or whey samples are delivered on a routine basis at agreed intervals to the phage lab of the culture supplier. In longer perspective, successful cooperation of culture suppliers and users in monitoring different culture rotation strategies allows designing sequences of culture rotation and safe intervals between rotations as well as elaborate the cleaning and disinfection strategy adapted to specific dairy environments (Fig.2).

Rotation strategy of defined multiple strain cultures demands selection of strains resistant to a wide range of phages, which could replace infected strains. This aspect can be a drawback when considering continuous and effective use of this method. Moreover, continual rotation of multiple strains during fermentation processes has an effect on phage co-evolution and was shown to increase phage diversity and their abundance in the dairy environment [133]. It also requires constant selection of starter strains with specific fermentative properties. An alternative is the use of a single, highly specialized phage-resistant strain and its variants carrying phage resistance plasmids obtained from naturally resistant strains. This strategy was termed by Sing and Klaenhammer as the phage defense rotation strategy (PDRS) [134]. The success of designed rotations systems of phage-resistant single strain derivatives is assessed by the Heap-Lawrence starter culture activity test (SAT) performed usually in phage-contaminated milk or whey from earlier cycles [135]. Continuous rotation in repeated cycles of single starter lactococcal strain derivatives, where each carries a different type or a combination of various phage defense systems (e.g. R/M or Abi), has been recognized as an effective method of limiting phages during industrial processes [134,136]. Sing and Klaenhammer have shown that the rotation system of three Lactococcus lactis derivative strains encoding different phage defense mechanisms provided resistance to the culture during nine rotation cycles against $10^{6} \mathrm{PFU} \mathrm{ml} \mathrm{m}^{-1}$ of whey composition containing as many as 160 phage isolates [134]. The strategy was then shown to demand precise determination of the type of defense systems to be used as well as the rotation order of the strains. Expression of several phage defense systems relying on different mechanisms conferred complementary defense against phage infection of single strain-derived cultures. Even if one defense system has been overcome, the phage can be inactivated by another. In the study of Durmaz and Klaenhammer (1995) three single starter Lactococcus lactis subsp. lactis derivatives, containing different plasmid-encoded phage defense mechanisms, were subjected to a 9-day rotation process challenged by two isometric phages (ul36 and Ф31) or a combination of 10 industrial phages at high titer [136]. Moreover, in most cases examined, an additive effect of different phage R/M and Abi defense systems was observed [136]. As assessed by SAT, the culture persisted incoming infections and only one $\Phi 31$-derived mutant phage was detected, but did not disturb culture growth during 17 rotation rounds. Based on these observations, it seems that continuous rotation of at least three derivatives of 
a single starter strain, where each carries a different phage defense system, is an attractive method to overcome phages as well as all types of resulting phage mutants. Moreover, the use of a limited number of strains, in this case one strain and its variants, limits the phage number as well as the occurrence of novel phages in fermentation plants [135,137]. A great advantage for the industry is also the use of only one indicator strain to monitor phage occurrence. Application of PDRS by construction of novel strains carrying newly identified phage-resistance mechanisms makes this strategy broad range with unlimited variants.

\subsection{Production organization}

An important element reducing the spread of phages in the dairy plant is the organization of production. The control of phage risk in dairy plants relies on development and implementation of a variety of procedures. To keep phages under control one should $[5,102,123]$ :

- $\quad$ perform daily tests for phage detection

- $\quad$ avoid crossing paths for raw milk, pasteurized milk and whey

- $\quad$ reduce the diversity of products made on a given day in one production hall

- $\quad$ rotate manufacturing processes

- directly inoculate milk with high concentrated cultures

- $\quad$ rotate starter cultures

- $\quad$ use anti-phage media for bulk starter (BS) propagation

- perform aseptic inoculation where possible

- $\quad$ use air filtration (HEPA) and positive pressure in production facilities

- use positive pressure in fermentation tanks where possible

- use steam sterilization of production lines where possible, especially when phage contamination is high

- dispose stagnant zones of water, whey, milk and foam from production hall or other liquid pools containing live cultures

- clean and disinfect lines, floors, walls, bins and drains used immediately after the process completion

- $\quad$ redisinfect lines after longer production break (e.g. weekend, bank holiday, breakdown)

- disinfect of small equipment used in milk processing after each use ( $\mathrm{pH}$-electrode, temperature sensors, etc.)

- $\quad$ use footbaths with disinfecting agents at the entry of production facilities

- $\quad$ avoid using the same equipment for raw milk and whey transportation and treatment

- $\quad$ separate fermentation and packaging areas

- limit personnel path movements (staff in contact with raw milk has no admission to the production facilities)

Plant staff should be aware of the importance of phage control risk, well acquainted with procedures and follow them. 


\section{Selection of phage tolerant strains}

\subsection{Classical methods (isolation and selection of phage tolerant strains against the most aggressive phages from the dairy environment)}

In order to isolate phage-resistant mutants, a secondary culture method can be used [138], in which sensitive strains undergo selective pressure of their specific phages. Sensitive strains are inoculated in liquid medium and subsequently infected with suspensions of a selected lytic phage at specific titer. Liquid cultures exhibiting complete lysis are incubated for 24-48 hours (secondary growth). After incubation, bacteria are streaked on adequate solid medium. The grown colonies are consecutively cultured in liquid medium with the same selected phage during at least three rounds. Resultant isolates that are able to grow normally in the presence of the specific phage are considered as true phage-resistant mutants [139].

Another means of natural selection of phage-resistant strains was developed by Viscardi and colleagues [140]. The approach is based on flow-cytometry technique that senses and selects bacterial cells to which phage particles that have been added to the medium did not adsorb. Two detection methods have been designed, which rely on recognition of either specifically labeled anti-phage antibodies or fluorochrome-stained phages. The presented method is an attractive alternative to other means of isolating phage-resistant strains (described earlier). In the study, several different Streptococcus thermophilus strains were analyzed for their potential to develop spontaneous phage resistance that could be detected by flow-cytometry technique. The designed selection methods proved quite sensitive, as phage-resistant cells could be detected after only one selection round. Nonetheless, a tworound selection based on selection with anti-phage antibodies or labeled phages and then with unlabeled phage alone was more efficient in obtaining stable and proper phageresistant mutants. Phage adsorption assays determined that majority of the isolated mutants resisted phage infection at the level of phage adsorption. Moreover, several selection rounds using different labeled phages lead to isolating multi-phage resistant cells.

The great advantage of the method is its high sensitivity (detection of 2 out $10^{7}$ cells) and high analysis rates $\left(10^{3}\right.$ cells per second). As the occurrence of spontaneous phage-resistant cells is rather low in nature, the method allows increasing the level of detection of such mutants. Furthermore, the selected S. thermophilus mutants were resistant to phage attack throughout multiple generations, indicating the stability of this property. The novelty of the method is the short amount (several days) of time necessary for obtaining phage-resistant mutants. This creates a possibility of fast selection of new resistant starter strains in the presence of novel phages, which constantly break away from the current defense systems.

\subsection{BIM system - exposure of sensitive strains to lytic phages (spontaneous mutation in chromosomal or plasmidic genes)}

Selection of BIMs (bacteriophage insensitive mutants) is a way to obtain phage-resistant strains without genetic manipulations. The idea of obtaining such cells is to infect a starter strain culture and select for mutants which have sustained phage attack. 
This approach has its drawbacks, as it is based solely on the occurrence of random potential mutations in genes coding for receptor materials. The lack of a functional initial receptor for 936- and P335-type phages, such as a polysaccharide, is associated with mutations in genes involved in its synthesis or transport. It is well documented that phage insensitivity of $L$. lactis strains is correlated with loss of the galactose-associated receptor in the cell wall. This disturbs the synthesis of wall components and, as a consequence, insensitive strains often lose their industrial properties, such as the ability to produce acids, and reveal weaker growth in comparison to wild type strains.

Apart from altering cell growth, other two features, such as narrow phage specificity and spontaneous reversion to sensitive phenotype, limit exploitation of BIM mutants in industrial applications [17]. However, mutations in the pip gene, encoding a specific receptor for c2-type phages only (for further details on Pip function see: 4 and 6.1-2.), have no significant impact on vitality of lactococcal cells and resultant mutants are stably maintained $[17,24]$. Genetic engineering methods, which possess a huge potential for developing protection against phages, based on specific point mutations, and construction of stable mutants, might be the solution to this problem. However, at present methods utilizing recombinant DNA approaches restrict the industrial use of genetically modified strains. Mills and colleagues presented a simple 3-step approach, devoid of genetic engineering methods, for generating BIMs of S. thermophilus [141]. In the first step, sensitive bacteria were completely lysed in soft top agar plates by adding a selected industrial phage at a MOI $>1$ (multiplicity of infection above 1). Subsequently, plates were incubated up to 48 hours after which appearance of resistant colonies was observed. In the next step, all colonies were collected and used to inoculate fresh liquid medium. Harvested bacteria from step 2 were used for conducting a continuous culture in milk with 20-25 passages in the presence of phage at a high concentration $(\mathrm{MOI}=10)$. In order to obtain BIM colonies, the last passage was poured on solid agar from which phage-resistant BIMs were selected after overnight growth. Resistance to another phage could be generated by repeating the whole process on the resultant BIM strain. The insensitive phenotype was initially attributed to nonspecific mutations in receptor genes. However, further studies revealed that phage insensitivity is due to alteration of the CRISPR (clustered regularly interspaced short palindromic repeats) locus, not associated with the previously thought mutations [142] (for further details on CRISPRs see section 6.5 and 12.4).

\subsection{Plasmid concept}

Among the acknowledged and widely applied methods of obtaining starter strains resistant to phage infections is conjugational transfer of plasmids conferring phage resistance determinants [143-144]. In lactococci, there is a range of bacteriophage defense systems occurring naturally on plasmids (natural, plasmid-encoded phage-resistance systems). Among the plasmid-encoded phage resistance are such defense mechanisms as restriction/modification $(\mathrm{R} / \mathrm{M})$ or abortive infection $\left(\mathrm{Hsp}^{+}\right.$or other $\mathrm{Abi}^{+}$) (for more details see sections: 6.3. and 6.4.). First studies, which linked the presence of phage resistance 
mechanisms to plasmid molecules, were simple assays based on isolation of plasmids from resistant strains and their reintroduction into susceptible cells to obtain cells immune to attack by a particular phage. The later discovery of phage resistance determinants encoded on conjugational plasmids attracted great interest of the food production industry. Most of the data on conjugative plasmids conferring phage resistance comes from studies in Lactococcus lactis. In this species many various conjugal plasmids conferring phageresistance have been identified, including: pTN20, pNP40 and pCI1750, carrying both conjugal transfer $\left(\mathrm{Tra}^{+}\right)$and abortive infection $\left(\mathrm{Abi}^{+}\right)$determinants, or pAJ1106, exhibiting $\mathrm{Tra}^{+}$and $\mathrm{Hsp}^{+}$phenotype [145-149]. Extensive studies of various research groups showed that indeed construction of phage-resistant strains via simple conjugational transfer is an effective means of generating phage resistant starter strains, some of which found application in the dairy industry [143,150].

Among the first conjugal plasmids discovered in Lactococcus lactis was pTR2030 isolated from strain ME2. It was characterized to encode heat-sensitive phage resistance $\left(\mathrm{Hsp}^{+}\right)$, restriction-modification (LlaIR/M) as well as conjugal transfer $\left(\mathrm{Tra}^{+}\right)$genes [151]. Its introduction via conjugation into other lactococcal strains, including Lactococcus lactis subsp. cremoris, resulted in phage-resistance phenotypes [152]. Application of these genetic elements was hence proclaimed as an attractive and acceptable alternative for generating resistant strains, in contrast to strain construction using genetic engineering. The study of Sanders et al. (1986) described the successful attempt of introducing the pTR2030 plasmid via conjugation from a $L$. lactis donor into several industrial recipient strains, from both lactis and cremoris subspecies [143]. Resulting transconjugants proved resistant to homologous phage infection. Curing of pTR2030 from transconjugants restored phage-sensitive phenotypes, proving visibly that phage resistance is conferred by the plasmid. Noteworthy is the fact that selection of phage-resistant transconjugants was performed in an antibioticfree background, which is most appropriate for manipulations with strains intended for food production. Another important advantage of this approach was the fact that transconjugant strains maintained their acid-producing properties. This aspect is quite important as it shows that conjugative plasmid manipulations do not alter the industrially attractive features of starter bacteria. The pTR2030 plasmid was maintained throughout multiple generations, indicating that phage resistance will be a stable feature during prolonged use of the transconjugant in industrial applications. Resistance mechanisms identified on conjugative plasmids were also applied in developing engineered bacterial phage defense systems, e.g. the LlaIR/M function encoded on the pTR2030 plasmid was used in constructing phage-triggered suicide systems (see section: 6.6.4.).

The plasmid-concept of generating phage-resistant strains has also its limitations. First of all, it should be taken into account that many industrially-applied strains are hard to transform. Furthermore, there is a chance that introduction of new plasmids might destabilize industrially attractive strain properties that are also plasmid-encoded (issue of plasmid incompatibility). Introduction of plasmids transferring phage resistance into the bacterial chromosome could be a way of stabilizing this feature; yet, on the other hand, will demand 
approval of appropriate authorities. Furthermore, some industrially-exploited lactic acid bacteria species, e.g. S. thermophilus, carry few plasmids (including conjugal plasmids). This can be an obstacle in generating novel phage-resistant strains via conjugational events [153]. Yet, studies performed by Burrus et al. (2001) revealed the presence of an integrative conjugative element ICRSt1 in S. thermophilus strain CNRZ368, shown to encode a II-type $\mathrm{R} / \mathrm{M}$ system that provided resistance to phage $\phi S T 84$ infection [154]. Identification of a phage defense system on an integrative element suggests that also such genetic elements as transposons can be responsible for the spread of phage-resistance mechanisms within bacterial populations.

\subsection{CRISPR/cas defense in LAB}

The CRISPR/cas defense system was first described in the 1980s for E. coli, but only recently recognized for lactic acid bacteria (2007), including such genera as Lactobacillus, Bifidobacterium, Symbiobacterium, Enterococcus and Streptococcus. Examination of more than 100 genomes of various LAB species allowed identifying over 60 different CRISPR loci, which were grouped into eight distinct families [155]. This indicates the highly diverse nature of LAB CRISPR loci. Additionally, it was observed that clustering of LAB CRISPRs was not in accordance with the classical phylogenetic correlations observed between the LAB phyla. This strongly implies that dissemination of CRISPR loci within the Prokaryotic world into separate lineages occurred by horizontal gene transfer events and their further evolution was imposed by the selective pressure due to phage infections. In general, CRISPR loci were determined to be located on the chromosome, except for one E. faecium strain found to carry the CRISPR array on a plasmid. Most LAB species harbor more than one CRISPR locus; yet, despite the common occurrence of CRISPR/cas systems, they have still not been identified for such species as Lactococcus, Leuconostoc, Carnobacterium, Pediococcus, and Oenococcus. This surprising absence of CRISPR loci was implied to be connected with an insufficient amount of sequencing data for these species in public databases. Examination of other strains of these species, involving genome sequencing, should be performed in order to fully resolve the issue on the existence of CRISPR/cas systems in these LABs. The identified various CRISPR arrays were determined to contain in total 100 different spacer sequences, including sequences of phage $(26 \%)$ or prophage $(47 \%)$ origin.

As CRISPR/cas systems confer phage resistance to host cells, they are quite of interest for the dairy industry where microbial production plays a significant role. Application of CRISPR/cas systems for construction of new LAB strain variants with differentiated resistance to phage infections is a novel alternative approach [67,142,156]. Moreover, such strains are regarded as safer for industrial applications, as the possibility for them to incorporate or disseminate foreign mobile genetic elements of unknown impact is low. Natural methods of selecting CRISPR-containing BIM cells (see section: 12.2.) of industrially applied bacteria could be an interesting solution for obtaining resistant strains, without deliberate genetic modifications. The first report on isolating CRISPR-containing lactic acid bacteria came from Barrangou et al. (2007) [67], who described the an approach of obtaining 
spontaneous S. thermophilus BIM cells by providing selection pressure due to phage infection. Protocols of isolating such strains have been later developed for dairy $S$. thermophilus, applied in the manufacturing of cheese and yoghurts [141]. The strategy is based on exposition of bacterial starter culture to high phage titers. Several rounds of growth in milk media under the constant selection pressure due to the phage presence resulted in obtaining phage-resistant mutants able to efficiently grow under industrial conditions. The great advantage of such approach is the fact that the presence of naturally acquired spacer sequences renders the strain resistant to phage infections, while preserving the industrially-attractive features of the initial starter cultures. Another strategy of constructing phage-resistant strains could be deliberate integration of synthetic spacers homologous to conserved sequences of industrial phage isolates into the CRISPR array of starter bacteria. However, this approach would involve certain molecular manipulations at the DNA level. Nonetheless, controlled modification of phage resistance of LAB strains using the CRISPR/cas regions is not considered by the food industry as a genetic modification method within the meaning of the existing rules in this area.

\section{Author details}

A.K. Szczepankowska, R.K. Górecki and J.K. Bardowski

Institute of Biochemistry and Biophysics of Polish Academy of Sciences, Warsaw, Poland

P. Kołakowski *

Danisco Biolacta, Innovation, Olsztyn, Poland

\section{References}

[1] Whitehead HR, Cox GA. The occurrence of bacteriophage in lactic streptococci. N. Z. J. Dairy Sci. Technol. 1935;16 319-320.

[2] Daly C, Fitzgerald GF, Davis R. Biotechnology of lactic acid bacteria with special reference to bacteriophage resistance. Antonie Van Leeuwenhoek 1996;70(2-4) 99-110.

[3] Lawrence R C. Action of bacteriophages on lactic acid bacteria: consequences and protection. N. Z. J. Dairy Sci. Technol. 1978;13 129-136.

[4] Brüssow H, Hendrix RW. Phage genomics: small is beautiful. Cell 2002;108(1) 13-6.

[5] Kołakowski P, Rybka J. Causes of disorders of fermentation failures (in Polish). BIBIT (Information Bulletin Rhodia Food Biolacta) 2001;2(24) 7-14.

[6] Klaenhammer T, Altermann E, Arigoni F, Bolotin A, Breidt F, Broadbent J, Cano R, Chaillou S, Deutscher J, Gasson M, van de Guchte M, Guzzo J, Hartke A, Hawkins T, Hols P, Hutkins R, Kleerebezem M, Kok J, Kuipers O, Lubbers M, Maguin E, McKay L, Mills D, Nauta A, Overbeek R, Pel H, Pridmore D, Saier M, van Sinderen D, Sorokin A, Steele J, O'Sullivan D, de Vos W, Weimer B, Zagorec M, Siezen R. Discovering lactic acid bacteria by genomics. Antonie Van Leeuwenhoek 2002;82(1-4) 29-58.

\footnotetext{
${ }^{*}$ Corresponding Author
} 
[7] Klaenhammer TR, Barrangou R, Buck BL, Azcarate-Peril MA, Altermann E. Genomic features of lactic acid bacteria effecting bioprocessing and health. FEMS Microbiol Rev. 2005;29(3) 393-409.

[8] Fox PF, McSweeney PLH. Cheese: An Overview. Cheese: Chemistry, Physics and Microbiology 2004;1 1-18.

[9] Ackermann HW, Kropinski AM. Curated list of prokaryote viruses with fully sequenced genomes. Res Microbiol. 2007;158(7) 555-566.

[10] Ackermann HW. Bacteriophage observations and evolution. Res Microbiol. 2003;154(4) 245-251.

[11] Ackermann HW. Frequency of morphological phage descriptions in the year 2000. Brief review. Arch Virol. 2001;146(5) 843-857.

[12] Hendrix RW. Bacteriophage genomics. Current Opinion in Microbiology 2003;6 506511.

[13] Breitbart M, Salamon P, Andresen B, Mahaffy JM, Segall AM, Mead D, Azam F, Rohwer F. Genomic analysis of uncultured marine viral communities. Proc Natl Acad Sci USA 2002;99(22) 14250-5.

[14] Yu MX, Slater MR, Ackermann HW. Isolation and characterization of Thermus bacteriophages. Arch Virol. 2006;151(4) 663-79.

[15] Breitbart M, Hewson I, Felts B, Mahaffy JM, Nulton J, Salamon P, Rohwer F. Metagenomic analyses of an uncultured viral community from human feces. J Bacteriol. 2003;185(20) 6220-6223.

[16] Mc Grath S, Fitzgerald GF, van Sinderen D. Bacteriophages in dairy products: pros and cons. Biotechnology Journal 2007;2(4) 450-455.

[17] Forde A, Fitzgerald GF. Bacteriophage defence systems in lactic acid bacteria. Antonie Van Leeuwenhoek 1999;76(1-4) 89-113.

[18] Heller K, Braun V. Polymannose O-antigens of Escherichia coli, the binding sites for the reversible adsorption of bacteriophage $\mathrm{T} 5+$ via the L-shaped tail fibers. J. Virol. 1982;41(1) 222-7.

[19] Dupont K, Janzen T, Vogensen FK, Josephsen J, Stuer-Lauridsen B. Identification of Lactococcus lactis genes required for bacteriophage adsorption. Appl Environ Microbiol. 2004;70(10) 5825-32.

[20] Babu KS, Spence WS, Monteville MR, Geller BL. Characterization of a cloned gene (pip) from Lactococcus lactis required for phage infection. Dev Biol Stand. 1995;85 569-75.

[21] Mooney DT, Jann M, Geller BL. Subcellular location of phage infection protein (Pip) in Lactococcus lactis. Can J Microbiol. 2006;52(7) 664-72.

[22] Kraus J, Geller BL. Membrane receptor for prolate phages is not required for infection of Lactococcus lactis by small or large isometric phages. J Dairy Sci. 1998;81(9) 2329-2335.

[23] Hoier E, Janzen T, Rattray F, Sorensen K, Borsting MW, Brockmann E. The production, application and action of lactic cheese starter cultures. In: Law BA, Tamime AY. (eds.) Technology of Cheese Making. Oxford UK: Wiley-Blakwell; 2010. p166-192. 
[24] Coffey A, Ross RP. Bacteriophage-resistance systems in dairy starter strains: molecular analysis to application. Antonie Van Leeuwenhoek 2002;82(1-4) 303-21.

[25] Tuncer Y, Akçelik M. A protein which masks galactose receptor mediated phage susceptibility in Lactococcus lactis subsp. lactis MPL56. International Journal of Food Science \& Technology 2002;37(2) 139-144.

[26] Forde A, Fitzgerald GF. Molecular organization of exopolysaccharide (EPS) encoding genes on the lactococcal bacteriophage adsorption blocking plasmid, pCI658. Plasmid 2003;49(2) 130-42.

[27] Watanabe K, Ishibashi K, Nakashima Y, Sakurai T. A Phage-resistant mutant of Lactobacillus casei which permits phage adsorption but not genome injection. J Gen Virol. 1984;65 981 - 986.

[28] Mahony J, McGrath S, Fitzgerald GF, van Sinderen D. Identification and characterization of lactococcal-prophage-carried superinfection exclusion genes. Appl Environ Microbiol. 2008;74(20) 6206-15.

[29] Garvey P, Hill C, Fitzgerald GF. The lactococcal plasmid pNP40 encodes a third bacteriophage resistance mechanism, one which affects phage DNA penetration. Appl Environ Microbiol. 1996;62(2) 676-679.

[30] McGrath S, Fitzgerald GF, van Sinderen D. Identification and characterization of phageresistance genes in temperate lactococcal bacteriophages. Mol Microbiol. 2002;43(2) 50920.

[31] Ventura M, Canchaya C, Pridmore RD, Brüssow H. The prophages of Lactobacillus johnsonii NCC 533: comparative genomics and transcription analysis. Virology 2004;320(2) 229-242.

[32] Sun X, Göhler A, Heller KJ, Neve H. The ltp gene of temperate Streptococcus thermophilus phage TP-J34 confers superinfection exclusion to Streptococcus thermophilus and Lactococcus lactis. Virology 2006;350(1) 146-57.

[33] Blumenthal RM, Cheng X. Restriction-modification systems. In: Streips UN, Yasbin RE. (eds.) Modern microbial genetics, 2nd ed. New York: Wiley; 2002. p177-226

[34] Seegers JF, van Sinderen D, Fitzgerald GF. Molecular characterization of the lactococcal plasmid pCIS3: natural stacking of specificity subunits of a type I restriction/modification system in a single lactococcal strain. Microbiology 2000;146(2) 435-443.

[35] Smith MA, Read CM, Kneale GG. Domain structure and subunit interactions in the type I DNA methyltransferase M.EcoR124I. J. Mol. Biol. 2001;314(1) 41-50.

[36] Murray NE. Type I restriction systems: sophisticated molecular machines (a legacy of Bertani and Weigle). Microbiol. Mol. Biol. Rev. 2000;64(2) 412-434.

[37] Janscak P, Bickle TA. The DNA recognition subunit of the type IB restrictionmodification enzyme EcoAI tolerates circular permutions of its polypeptide chain. J Mol Biol. 1998;284(4) 937-948.

[38] Janscak P, Dryden DT, Firman K. Analysis of the subunit assembly of the type IC restriction-modification enzyme EcoR124I. Nucleic Acids Res. 1998;26(19) 4439-45. 
[39] O'Sullivan D, Twomey DP, Coffey A, Hill C, Fitzgerald GF, Ross RP. Novel type I restriction specificities through domain shuffling of HsdS subunits in Lactococcus lactis. Mol. Microbiol. 2000;36(4) 866-75.

[40] Gorecki RK, Koryszewska-Bagińska A, Gołębiewski M, Żylińska J, Grynberg M, Bardowski J. Adaptative potential of the Lactococcus lactis IL594 strain encoded in its 7 plasmids. PLoS ONE 2011;6(7) e22238.

[41] Adamczyk-Popławska M, Kondrzycka A, Urbanek K, Piekarowicz A. Tetra-amino-acid tandem repeats are involved in HsdS complementation in type IC restrictionmodification systems. Microbiology 2003;149(11) 3311-3319.

[42] [42]Holubova I, Vejsadova S, Firman K, Weiserova M. Cellular localization of Type I restriction-modification enzymes is family dependent. Biochem Biophys Res Commun 2004;319(2) 375-380.

[43] Keatch SA, Su TJ, Dryden DT. Alleviation of restriction by DNA condensation and nonspecific DNA binding ligands Nucleic Acids Res. 2004;32(19) 325841-5850.

[44] Pingoud A, Fuxreiter M, Pingoud V, Wende W. Type II restriction endonucleases: structure and mechanism. Cell Mol. Life Sci. 2005;62(6) 685-707.

[45] Pingoud A, Jeltsch A. Structure and function of type II restriction endonucleases. Nucleic Acids Res. 2001;29(18) 3705-27.

[46] Marshall JJ, Gowers DM, Halford SE. Restriction endonucleases that bridge and excise two recognition sites from DNA. J Mol Biol. 2007;367(2) 419-431.

[47] Gowers DM, Bellamy SRW, Halford SE. One recognition sequence, seven restriction enzymes, five reaction mechanisms. Nucl. Acids Res. 2004;32(11) 3469-3479.

[48] Marks P, McGeehan J, Wilson G, Errington N, Kneale G. Purification and characterisation of a novel DNA methyltransferase, M.AhdI. Nucleic Acids Res. 2003;31(11) 2803-2810.

[49] Szybalski W, Kim SC, Hasan N, Podhajska AJ. Class-IIS restriction enzymes-a review. Gene 1991;100 13-26.

[50] Christensen LL, Josephsen J. The methyltransferase from the LlaDII restriction modification system influences the level of expression of its own gene. J Bacteriol. 2004;186(2) 287-295.

[51] Su P, Im H, Hsich H, Kang AS, Dunn NW. LlaFI, a type III restriction and modification system in Lactococcus lactis. Appl Environ Microbiol. 1999;65(2) 686-693.

[52] Guinane CM, Kent RM, Norberg S, Hill C, Fitzgerald GF, Stanton C, Ross RP. Host specific diversity in Lactobacillus johnsonii as evidenced by a major chromosomal inversion and phage resistance mechanisms. Plos One 2011;6 e18740.

[53] Su P, Im H, Hsieh H, Kang AS, Dunn NW. LlaFI, a type III restriction and modification system in Lactococcus lactis. Appl. Environ. Microbiol 1999;65(2) 686-93

[54] Solow BT, Somkuti GA. Molecular properties of Streptococcus thermophilus plasmid pER35 encoding a restriction modification system. Curr Microbiol 2001;42(2) 122-128.

[55] Hao P, Zheng H, Yu Y, Ding G, Gu W, Chen S, Yu Z, Ren S, Oda M, Konno T, Wang S, Li X, Ji ZS, Zhao G. Complete sequencing and pan-genomic analysis of Lactobacillus 
delbrueckii subsp. bulgaricus reveal its genetic basis for industrial yogurt production. PLoS ONE 2011;6(1) e15964.

[56] Janulaitis A, Petrusyte M, Maneliene Z, Klimasauskas S, Butkus V. Purification and properties of the Eco57I restriction endonuclease and methylase-prototypes of a new class (type IV). Nucleic Acids Res. 1992;20(22) 6043-6049.

[57] O'Sullivan O, O'Callaghan J, Sangrador-Vegas A, McAuliffe O, Slattery L, Kaleta P, Callanan M, Fitzgerald GF, Ross RP, Beresford T. Comparative genomics of lactic acid bacteria reveals a niche-specific gene set. BMC Microbiol. 2009;5 9-50.

[58] Chopin MC, Chopin A, Bidnenko E. Phage abortive infection in lactococci: variations on a theme. Curr. Opin. Microbiol. 2005;8(4) 473-479.

[59] Durmaz E, Klaenhammer TR. Abortive phage-resistance mechanism AbiZ speeds the lysis clock to cause premature lysis of phage-infected Lactococcus lactis. J Bacteriol. 2007;189(4) 1417-1425.

[60] Haaber J, Fortier LC, Moineau S, Hammer K. AbiV, a novel abortive phage infection mechanism on the chromosome of Lactococcus lactis subsp. cremoris MG1363. Appl. Environ. Microbiol. 2008;74(21) 6528-6537.

[61] Prevots F, Tolou S, Delpech B, Kaghad M, Daloyau M. Nucleotide sequence and analysis of the new chromosomal abortive infection gene abiN of Lactococcus lactis subsp. cremoris S114. FEMS Microbiol Lett. 1998;159(2) 331-336.

[62] O'Connor L, Tangney M, Fitzgerald GF. Expression, regulation, and mode of action of the AbiG abortive infection system of Lactococcus lactis subsp. cremoris UC653. Appl. Environ. Microbiol. 1999;65(1) 330-335.

[63] Twomey DP, De Urraza PJ, McKay LL, O'Sullivan DJ. Characterization of AbiR, a novel multicomponent abortive infection mechanism encoded by plasmid pKR223 of Lactococcus lactis subsp. lactis KR2. Appl Environ Microbiol. 2000;66(6) 2647-2651.

[64] Domingues S, McGovern S, Plochocka D, Santos MA, Ehrlich SD, Polard P, Chopin MC. The lactococcal abortive infection protein AbiP is membrane-anchored and binds nucleic acids. Virology 2008;373(1) 14-24.

[65] Emond E, Dion E, Walker SA, Vedamuthu ER, Kondo JK, Moineau S. AbiQ, an abortive infection mechanism from Lactococcus lactis. Appl Environ Microbiol. 1998;64(12) 47484756.

[66] Horvath P, Barrangou P. CRISPR/Cas, the immune system of Bacteria and Archea. Science 2010;327(5962) 167-170.

[67] Barrangou R, Fremaux C, Deveau H, Richards M, Boyaval P, Moineau S, Romero DA, Horvath P. CRISPR provides acquired resistance against viruses in prokaryotes. Science 2007;315(5819) 1709-1712.

[68] Lillestøl RK, Shah SA, Brügger K, Redder P, Phan H, Christiansen J, Garrett RA. CRISPR families of crenarcheal genus Sulfolobus: bidirectional transcription and dynamic properties. Mol Microbiol 2006;72(1) 259-272. 
[69] Szczepankowska AK. Role of CRISPR/cas system in the development of bacteriophage resistance. In: Łobocka M, Szybalski WT. (eds.) Advances in Virus Research 82 (part A). USA: Academic Press (ELSEVIER); 2012. p289-338.

[70] Rousseau C, Nicolas J, Gonnet, M. CRISPI: A CRISPR Interactive database. Bioinformatics 2009;25(24) 3317-3318.

[71] Sturino JM, Klaenhammer TR. Engineered bacteriophage-defense systems in bioprocessing. Nat. Rev. Microbiol. 2006;4(5) 395-404.

[72] Inouye M. Antisense RNA: its functions and applications in gene regulation - a review. Gene 1988;72(1-2) 25-34.

[73] Sturino JM, Klaenhammer TR. Expression of antisense RNA targeted against Streptococcus thermophilus bacteriophages. Appl. Environ. Microbiol. 2002;68(2) 588-596.

[74] Sturino JM, Klaenhammer TR. Antisense RNA targeting of primase interferes with bacteriophage replication in Streptococcus thermophilus. Appl. Environ. Microbiol. 2004;70(3) 1735-1743.

[75] Brüssow H, Probst A, Frémont M, Sidoti J. Distinct Streptococcus thermophilus bacteriophages share an extremely conserved DNA fragment. Virology 1994;200(2) 854857.

[76] Kim SG, Bor YC, Batt CA. Bacteriophage resistance in Lactococcus lactis subsp. lactis using antisense ribonucleic acid. J. Dairy Sci. 1992;75(7) 1761-1767.

[77] Chung DK, Chung SK, Batt CA. Antisense RNA directed against the major capsid protein of Lactococcus lactis subsp. cremoris bacteriophage F4-1 confers partial resistance to the host. Appl. Microbiol. Biotechnol. 1992;37(1) 79-83.

[78] Kim SG, Batt CA. Antisense mRNA-mediated bacteriophage resistance in Lactococcus lactis subsp. lactis. Appl. Environ. Microbiol. 1991;57(4) 1109-1113.

[79] McGrath S, Fitzgerald GF, van Sinderen D. Improvement and optimization of two engineered phage resistance mechanisms in Lactococcus lactis. Appl. Environ. Microbiol. 2001;67(2) 608-616.

[80] Hill C, Miller LA, Klaenhammer TR. Cloning, expression, and sequence determination of a bacteriophage fragment encoding bacteriophage resistance in Lactococcus lactis. J. Bacteriol. 1990;172(11) 6419-6426.

[81] O'Sullivan DJ, Hill C, Klaenhammer TR. Effect of increasing the copy number of bacteriophage origins of replication, in trans, on incoming-phage proliferation. Appl. Environ. Microbiol. 1993; 59(8) 2449-2456.

[82] Foley S, Lucchini S, Zwahlen MC, Brüssow H. A short noncoding viral DNA element showing characteristics of a replication origin confers bacteriophage resistance to Streptococcus thermophilus. Virology 1998;250(2) 377-387.

[83] Stanley E, Walsh L, van der Zwet A, Fitzgerald GF, van Sinderen D. Identification of four loci isolated from two Streptococcus thermophilus phage genomes responsible for mediating bacteriophage resistance. FEMS Microbiol. Lett. 2000;182(2) 271-277. 
[84] Bruttin A, Desiere F, Lucchini S, Foley S, Brüssow H. Characterization of the lysogeny DNA module from the temperate Streptococcus thermophilus bacteriophage Sfi21. Virology 1997;233(1) 136-148.

[85] Bruttin A, Foley S, Brüssow H. DNA-binding activity of the Streptococcus thermophilus phage Sfi21 repressor. Virology 2002;303(1) 100-109.

[86] Bruttin A, Foley S, Brüssow, H. The site-specific integration system of the temperate Streptococcus thermophilus bacteriophage Sfi21. Virology 1997;237(1) 148-158.

[87] Engel G, Altermann E, Klein JR, Henrich B. Structure of a genome region of the Lactobacillus gasseri temperate phage phi adh covering a repressor gene and cognate promoters. Gene 1998;210(1) 61-70.

[88] Alvarez MA, Rodriguez A, Suárez JE. Stable expression of the Lactobacillus casei bacteriophage A2 repressor blocks phage propagation during milk fermentation. J. Appl. Microbiol. 1999;86(5) 812-816.

[89] Madsen PL, Johansen AH, Hammer K, Brøndsted L. The genetic switch regulating activity of early promoters of the temperate lactococcal bacteriophage TP901-1. J. Bacteriol. 1999;181(24) 7430-7438.

[90] Djordjevic GM, O'Sullivan DJ, Walker SA, Conkling MA, Klaenhammer TR. A triggered-suicide system designed as a defense against bacteriophages. J. Bacteriol. 1997;179(21) 6741-6748.

[91] O'Sullivan DJ, Walker SA, West SG, Klaenhammer TR. Development of an expression strategy using a lytic phage to trigger explosive plasmid amplification and gene expression. Biotechnology 1996;14(1) 82-87.

[92] Djordjevic GM, Klaenhammer TR. Bacteriophage-triggered defense systems: phage adaptation and design improvements. Appl. Environ. Microbiol. 1997;63(11) 4370-4376.

[93] O'Sullivan DJ, Klaenhammer TR. C LlaI is a bifunctional regulatory protein of the llaI restriction modification operon from Lactococcus lactis. Dev. Biol. Stand. 1995; 85: 591595.

[94] Durmaz E, Madsen SM, Israelsen H, Klaenhammer TR. Lactococcus lactis lytic bacteriophages of the P335 group are inhibited by overexpression of a truncated CI repressor. J. Bacteriol. 2002;184(23) 6532-6544.

[95] Sturino JM, Klaenhammer TR. Inhibition of bacteriophage replication in Streptococcus thermophilus by subunit poisoning of primase. Microbiology 2007;153(10) 3295-3302.

[96] Lucchini S, Sidoti J, Brüssow H. Broad-range bacteriophage resistance in Streptococcus thermophilus by insertional mutagenesis. Virology 2000;275(2) 267-277.

[97] Garbutt KC, Kraus J, Geller BL. Bacteriophage resistance in Lactococcus lactis engineered by replacement of a gene for a bacteriophage receptor. J. Dairy Sci. 1997;80 1512-1519.

[98] Pedersen MB, Jensen PR, Janzen T, Nilsson D. Bacteriophage resistance of a $\Delta$ thy $A$ mutant of Lactococcus lactis blocked in DNA replication. Appl. Environ. Microbiol. 2002;68(6) 3010-3023.

[99] Nilsson D, Janzen T. Method of preventing bacteriophage infection of bacterial cultures. International patent application no. PCT/DK99/00382 (1998). 
[100] Kenny E, Atkinson T, Hartley BS. Nucleotide sequence of the thymidylate synthase gene (thyP3) from the Bacillus subtilis phage Ф3T. Gene 1985;34(2-3) 335-342.

[101] Powell IB, Tulloch DL, Hillier AJ, Davidson BE. Phage DNA synthesis and host DNA degradation in the life cycle of Lactococcus lactis bacteriophage c6A. J. Gen. Microbiol. 1992;138(5) 945-950.

[102] Moineau S, Levesque C. Control of bacteriophages in industrial fermentations. In: Kutter, Sulakvelidze A. (Eds.) Bacteriophages: Biology and Applications. Boca Raton, USA: CRC Press; 2005. p285-296.

[103] Carlson K. Appendix: Working with bacteriophages common techniques and methodological approaches. In: Kutter, Sulakvelidze A. (Eds.) Bacteriophages: Biology and Applications. Boca Raton, USA: CRC Press; 2005. p435-492.

[104] Garneau JE, Moineau S. Bacteriophages of lactic acid bacteria and their impact on milk fermentations. Microbial Cell Factories 2011;10(Suppl 1) S20, 1-10. http://www.microbialcellfactories.com/content/10/S1/S20.

[105] Labrie S, Moineau S. Multiplex PCR for detection and identification of lactococcal bacteriophages. Applied and Environmental Microbiology 2000;66(3) 987-994.

[106] Del Rio B, Binetti AG, Martin MC, Fernandez M, Magadan AH, Alvarez MA. Multiplex PCR for the detection and identification of dairy bacteriophages in milk. Food Microbiology 2007;24(1) 75-81.

[107] Martin MC, del Rio B, Martinez N, Magadan AH, Alvarez MA. Fast real-time polymerase chain reaction for quantitative detection of Lactobacillus delbrueckii bacteriophages in milk. Food Microbiology 2008;25(8) 978-982.

[108] Binetti AG, De Rio B, Martin MC, Alvarez MA. Detection and characterization of Streptococcus thermophilus bacteriophages by use of the antireceptor gene sequence. Appl. Environ. Microbiol. 2005;71(10) 6096-6103.

[109] Kleppen HP, Bang T, Nes IF, Holo H. Bacteriophages in milk fermentations: diversity fluctuations of normal and failed fermentations. International Dairy Journal 2011;21(9) 592-600.

[110] Madera C, Monjardin C, Suarez JE. Milk contamination and resistance to processing conditions determine the fate of Lactococcus lactis bacteriophages in dairies. Applied and Environmental Microbiology 2004;70(12) 7365-7371.

[111] Atamer Z, Ali Y, Neve H, Heller KJ, Hinrichs J. Thermal resistance of bacteriophages attacking flavor-producing dairy Leuconostoc starter cultures. International Dairy Journal, 2011;21(5) 327-334.

[112] Chopin MC. Resistance of 17 mesophilic lactic Streptococcus bacteriophages to pasteurization and spray-drying. Journal of Dairy Research 1980;47(1) 131-139.

[113] Canchaya C, Proux C, Fournous G, Bruttin A, Brüssov H. Prophage genomics. Microbiology and Molecular Biology Reviews 2003;67(2) 238-276.

[114] Mercanti DJ, Carminati D, Reinheimer JA, Quiberoni A. Widely distributed lysogeny in probiotic lactobacilli represents a potentially high risk for the fermentative dairy industry. International Journal of Food Microbiology 2011; 144(3) 503-510. 
[115] Lunde M, Aastveit AH, Blatny JM, Nes IF. Effects of diverse environmental conditions on $\phi \mathrm{LC} 3$ prophage stability in Lactococcus lactis. Applied Environmental Microbiology 2005;71(2) 721-727.

[116] Madera C, Garcia P, Rodriguez A, Suarez JE, Martinez B. Prophage induction in Lactococcus lactis by the bacteriocin Lactococcin 972. International Journal of Food Microbiology 2009;129(1) 99-102.

[117] Lunde M, Blatny JM, Lillehaug D, Aastveit AH, Nes IF. Use of real-time quantitative PCR for the analysis of $\phi L C 3$ prophage stability in lactococci. Applied Environmental Microbiology 2003;69(1) 41-48.

[118] Verreault D, Gendron L, Rousseau GM, Veillette M, Masse D, Lindsley WG, Moineau S, Duchaine C. Detection of airborne lactococcal bacteriophages in cheese manufacturing plants. Applied and Environmental Microbiology 2011;77(2) 491497.

[119] Neve H, Kemper U, Geis A, Heller KJ. Monitoring and characterization of lactococcal bacteriophages in a dairy plant. Kieler Milchw. Forsh. 1994;46 167-178

[120] Neve H, Laborius A, Heller KJ. Testing of the applicability of battery-powered portable microbial air samplers for detection and enumeration of airborne Lactococcus lactis dairy bacteriophages. Kieler Milchw. Forsh. 2003;55(4) 301-315.

[121] Kołakowski P, Rybka J, Fetlinski A. Bacteriophages in milk industry (in Polish). BIBIT (Information Bulletin Rhodia Food Biolacta) 2001;3(25) 8-11.

[122] Simoes M, Simoes LC, Vieira MJ. A review of current and emergent biofilm control strategies. LWT-Food Science and Technology 2010;43(4) 573-583.

[123] Primrose SB. Controlling bacteriophage infections in industrial bioprocesses. Advances in Biochemical Engineering Biotechnology 1990;43 1-10.

[124] Deutsches Institut Fur Normung E.V. DIN EN 13610:2002. Chemical disinfectantsQuantitative suspension test for the evaluation of virucidal activity against bacteriophages of chemical disinfectants used in food and industrial areas- Test method and requirements (phase2, step1); 2003.

[125] Guglielmotti DM, Mercanti DJ, Reinheimer JA, Quiberoni AL. Rewiev: efficiency of physical and chemical treatments on the inactivation of dairy bacteriophages. Frontiers in Microbiology 2011;2(282) 282-297

[126] Simoes M, Simoes LC, Machado I, Pereira MO, Vieira MJ. Control of flow generated biofilms using surfactants - evidence of resistance and recovery. Food and Bioproducts Processing 2006;84(4) 338-345.

[127] Briggiler MM, De Antoni GL, Reinheimer JA, Quiberoni A. Thermal, chemical, and photocatalytic inactivation of Lactobacillus plantarum bacteriophages. Journal of Food Protection 2009;72(5) 1012-1019.

[128] Buzrul S, Ozturk P, Alpas H, Akcelik M. Thermal and chemical inactivation of lactococcal bacteriophages. LWT Food Science Technology 2007;40(10) 1671-1677. 
[129] Capra ML, Quiberoni A, Reinheimer JA. Thermal and chemical resistance of Lactobacillus casei and Lactobacillus paracasei bacteriophages. Letters Applied Microbiology 204;38(6) 499-504.

[130] Suarez VB, Reinheimer JA. Effectiveness of thermal treatments and biocides in the inactivation of Argentinian Lactococcus lactis phages. Journal Food Protection 2002;65(11) 1756-1759.

[131] Thunell RK, Sandine WE. Types of starter cultures. In: Gilland SE. (ed.) Bacterial starter cultures for foods. Boca Raton USA: CRC Press; 1985. p127-144.

[132] Cogan TM, Peitersen N, Sellars RL. Starter systems. In: Bulletin of the International Dairy Federation, no. 263/1991. Practical phage control. International Dairy Federation, Brussels. 1991; p16-23.

[133] Heap HA, Lawrence RC. The contribution of starter strains to the level of phage infection in a commercial cheese factor. N. Z. J. Dairy Sci. Technol. 1977;12(4) 213.

[134] Sing WD, Klaenhammer TR. A strategy for rotation of different bacteriophage defenses in a lactococcal single-strain starter culture system. Appl. Environ. Microbiol. 1993;59(2) 365-372.

[135] Heap HA, Lawrence RC. The selection of starter strains for cheesemaking. N. Z. J. Dairy Sci. Technol. 1976;11(1) 16-20.

[136] Durmaz E, Klaenhammer TR. A starter culture rotation strategy incorporating paired restriction/modification and abortive infection bacteriophage defenses in a single Lactococcus lactis strain. Appl. Environ. Microbiol. 1995; 61(4) 1266-1273.

[137] Thunell RK, Sandine WE, Bodyfelt FW. Phage-insensitive, multiple-strain starter approach to cheddar cheesemaking. J. Dairy Sci. 1981;64(11) 2270-2277.

[138] Quiberoni A, Reinheimer JA, Tailliez P. Characterization of Lactobacillus helveticus spontaneous phage resistant mutants by RAPD-PCR fingerprints and phenotypic parameters. Food Research International 1998;31(8) 537-542.

[139] Guglielmotti DM, Reinheimer JA, Binetti AG, Giraffa G, Carminati D, Quiberoni A. Characterization of spontaneous phage-resistant derivatives of Lactobacillus delbrueckii commercial strains. Int J Food Microbiol. 2006;111(2) 126-33.

[140] Viscardi M, Capparelli R, Di Matteo R, Carminati D, Giraffa G, Iannelli D. Selection of bacteriophage-resistant mutants of Streptococcus thermophilus. J. Microbiol. Met. 2003;55(1) 109-119.

[141] Mills S, Coffey A, McAuliffe OE, Meijer WC, Hafkamp B, Ross RP. Efficient method for generation of bacteriophage insensitive mutants of Streptococcus thermophilus yoghurt and mozzarella strains. J Microbiol Methods 2007;70(1) 159-64.

[142] Mills S, Griffin C, Coffey A, Meijer WC, Hafkamp B, Ross RP. CRISPR analysis of bacteriophage-insensitive mutants (BIMs) of industrial Streptococcus thermophilusimplications for starter design. J Appl Microbiol. 2010;108(3) 945-55.

[143] Sanders ME, Leonhard PJ, Sing WD, Klaenhammer TR. Conjugal strategy for construction of fast acid-producing, bacteriophage-resistant lactic streptococci for use in dairy fermentations. Appl. Environ. Microbiol. 1986;52(2) 1001-1007. 
[144] Pillidge CJ, Collins LJ, Ward LJH, Cantillon BM, Shaw BD, Timmins MJ, Heap HA, Polzin KM. Efficacy of four lactococcal phage resistance plasmids against phage in commercial Lactococcus lactis subsp. cremoris cheese starter strains. Int. Dairy J. 2000;10(9) 617- 625.

[145] McKay LL, Baldwin KA. Conjugative 40-megadalton plasmid in Streptococcus lactis subsp. diacetylactis DRC3 is associated with resistance to nisin and bacteriophage. Appl. Environ. Microbiol. 1983;47(1) 68-74.

[146] Higgins DL, Sanozky-Dawes RB, Klaenhammer TR. Restriction and modification activities from Streptococcus lactis ME2 are encoded by a self-transmissible plasmid, pTN20, that forms cointegrates during mobilization of lactose-fermenting ability. J. Bacteriol. 1988;170(8) 3435-3442.

[147] Coffey A, Fitzgerald GF, Daly C. Identification and characterization of a plasmid encoding phage abortive infection from Lactococcus lactis ssp. lactis UC811. Netherlands Milk and Dairy Journal 1989;43(3) 229-244.

[148] Jarvis AW, Heap HA, Limsowtin GKY. Resistance against industrial bacteriophages conferred on lactococci by plasmid pAJ1106 and related plasmids. Appl. Environ. Microbiol. 1989;55(6) 1537-1543.

[149] Harrington A, Hill C. Construction of a bacteriophage-resistant derivative of Lactococcus lactis subsp. lactis 425A by using the conjugal plasmid pNP40. Appl. Environ. Microbiol. 1991;57(12) 3405-3409.

[150] Alatossava T, Klaenhammer TR. Molecular characterization of three small isometricheaded bacteriophages which vary in their sensitivity to the lactococcal phage resistance plasmid pTR2030. Appl. Environ. Microbiol. 1991;57(5) 1346-1353.

[151] Klaenhammer TR, Sanozky RB. Conjugal transfer from Streptococcus lactis ME2 of plasmids encoding phage resistance, nisin resistance and lactose-fermenting ability: evidence for a high-frequency conjugative plasmid responsible for abortive infection of virulent bacteriophage. J. Gen. Microbiol. 1985;131(6) 1531-1541.

[152] Steenson LR, Klaenhammer TR. Streptococcus cremoris M12R transconjugants carrying the conjugal plasmid pTR2030 are insensitive to attack by lytic bacteriophages. Appl. Environ. Microbiol. 1985;50(4) 851-858.

[153] Mercenier A. Molecular genetics of Streptococcus thermophilus. FEMS Microbiol. Rev. 1990;87 61-78.

[154] Burrus V, Bontemps C, Decaris B, Guédon G. Characterization of a novel type II restriction-modification system, Sth368I, encoded by the integrative element ICESt1 of Streptococcus thermophilus CNRZ368. Appl. Environ. Microbiol. 2001;67(4) 15221528.

[155] Horvath P, Coûté-Monvoisin AC, Romero DA, Boyaval P, Fremaux C, Barrangou R. Comparative analysis of CRISPR loci in lactic acid bacteria genomes. Int. J. Food Microbiol. 2009;131(1) 62-70. 
[156] Horvath P, Romero DA, Coûté-Monvoisin AC, Richards M, Deveau H, Moineau S, Boyaval P, Fremaux C, Barrangou R. Diversity, activity, and evolution of CRISPR loci in Streptococcus thermophilus. J. Bacteriol. 2008;190(4) 1401-1412. 